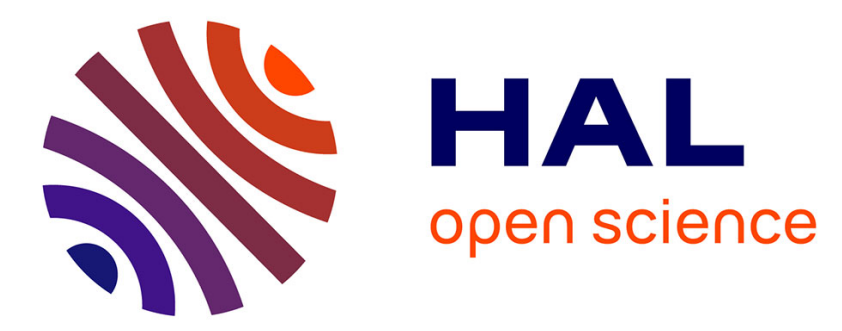

\title{
Distribution of rare earth elements in sediments of the North China Plain: A probe of sedimentation process
}

Haiyan Liu, Huaming Guo, Olivier Pourret, Zhen Wang, Zhanxue Sun, Weimin Zhang, Maohan Liu

\section{- To cite this version:}

Haiyan Liu, Huaming Guo, Olivier Pourret, Zhen Wang, Zhanxue Sun, et al.. Distribution of rare earth elements in sediments of the North China Plain: A probe of sedimentation process. Applied Geochemistry, 2021, 134, pp.105089. 10.1016/j.apgeochem.2021.105089 . hal-03332529

\section{HAL Id: hal-03332529 \\ https://hal.science/hal-03332529}

Submitted on 2 Sep 2021

HAL is a multi-disciplinary open access archive for the deposit and dissemination of scientific research documents, whether they are published or not. The documents may come from teaching and research institutions in France or abroad, or from public or private research centers.
L'archive ouverte pluridisciplinaire HAL, est destinée au dépôt et à la diffusion de documents scientifiques de niveau recherche, publiés ou non, émanant des établissements d'enseignement et de recherche français ou étrangers, des laboratoires publics ou privés. 


\section{Distribution of rare earth elements in sediments of the North China}

\section{Plain: A probe of sedimentation process}

Haiyan Liu ${ }^{1,2}$, Huaming Guo ${ }^{3, *}$, Olivier Pourret ${ }^{4}$, Zhen Wang ${ }^{1,2}$, Zhanxue Sun $^{1,2}$, Weimin Zhang $^{1,2}$, Maohan Liu ${ }^{1}$

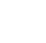
${ }^{1}$ School of Water Resources and Environmental Engineering, East China University of Technology, Nanchang 330013, P. R. China

${ }^{2}$ State Key Laboratory of Nuclear Resources and Environment, East China University of Technology, Nanchang 330013, P. R. China

${ }^{3}$ School of Water Resources and Environment, China University of Geosciences (Beijing), Beijing 100083, P.R. China

\footnotetext{
${ }^{4}$ UniLaSalle, AGHYLE, Beauvais, France
}

* Corresponding author: Huaming Guo

School of Water Resources and Environment,

China University of Geosciences (Beijing),

Beijing 100083, P. R. China

Tel.: +86-10-8232-1366

Fax: +86-10-8232-1081

1 E-mail address: hmguo@cugb.edu.cn (H. Guo) 
Abstract: Rare earth elements (REE) are powerful tracers for our understanding of sedimentary provenance and depositional processes. This study investigated geochemical characteristics of REE in 226 sediment samples collected from piedmont, central and littoral plains of the North China Plain. Results showed that total REE concentrations exhibited a decreasing trend as piedmont $>$ central $>$ littoral, and $82 \%$, $70 \%$ and $67 \%$ samples had total REE concentrations higher than the value of Upper Continental Crust. The REE concentrations were controlled by sedimentary provenance and sediment physicochemical properties. Ternary diagrams of sandstone classification and $\mathrm{Al}_{2} \mathrm{O}_{3}-\mathrm{CaO}+\mathrm{Na}_{2} \mathrm{O}-\mathrm{K}_{2} \mathrm{O}$ reflected that sediments originated from greywackes and they experienced an incipient to intermediate chemical weathering. Average Chemical Index of Alteration values were 68, 51 and 55 for sediments from piedmont, central and littoral sediments, respectively. Sediment North American Shale Composite (NASC)-normalized patterns were characterized by light REE (LREE) enrichment over heavy REE (HREE) and coherent negative Eu anomalies $\left(\mathrm{Eu} / \mathrm{Eu}^{*}\right.$ ranging between 0.57 and 1.00$)$. Value of $(\mathrm{La} / \mathrm{Yb})_{\mathrm{NASC}}$ ranged from 0.86 to 1.15 (average 1.23 ), and from 1.03 to 1.49 , and from 0.91 to 1.49 in three zones, indicating REE fractionation from piedmont to littoral occurred during sedimentation processes. A positive correlation between $(\mathrm{La} / \mathrm{Yb})_{\mathrm{NASC}}$ and total REE concentrations was observed in piedmont and central sediment samples, implying that LREE were preferentially enriched over HREE with an accumulation of REE. This positive correlation was not found in littoral sediment samples, where a general decreasing trend along depth for REE concentrations existed. Results of this study shows 
45 implications for using REE as a tracer in provenance studies from a basin scale.

46

47 Keywords: Lanthanides; Geochemistry; Sedimentation; Fractionation; Critical Zone

48 


\section{Introduction}

Rare earth elements are the lanthanides with atomic numbers ranging from 57 (La, lanthanum) to 71 (Lu, lutetium) (Henderson, 1984) as well as yttrium (Y, atomic number 39) and scandium (Sc, atomic number 21; Tyler, 2004). The geochemical signatures of rare earth elements and yttrium (thereafter denoted REE) in sediments and sedimentary rocks are powerful tracers to delineate the geochemical processes. These include magmatism, chemical weathering, diagenesis, erosion and water-rock interactions (McLennan, 1989). As a result, the concentrations and fractionations of REE in sediments and soils have received considerable attention in the past few decades.

Numerous investigations have been devoted to studying geochemical behaviors and mobility of REE in sediments and soils, including lake, river and marine sediments (Pourret and Tuduri, 2017; Xu et al., 2018, Wang et al., 2018; Consani et al., 2020), mining surroundings ( $\mathrm{Hu}$ et al., 2004; Wang and Liang, 2015), wetlands (Davranche et al., 2011; Cheng et al., 2012), agricultural areas (Silva et al., 2015; Han et al., 2017), alluvial deposits (Pédrot et al., 2015; Xie et al., 2014), unconsolidated clay sediments (Guo et al., 2010; Sá Paye et al., 2016) and sedimentary rocks (McLennan, 2001; Šmuc et al., 2012). It's recognized that REE concentrations and distributions in sediments depend on sedimentary provenance and sediment physicochemical properties. Significant correlations between REE concentrations and contents of clay and metals (i.e. Fe, Mn, Al) were observed by Mihajlovic and Rinklebe (2018); while $\mathrm{pH}$ value and cation exchange capacity were shown not 
important factors in their study. Grain size impacted REE concentrations in sediment as well. This is indicated by the results of Kimoto et al. (2006), showing that decreasing grain size generally increased REE concentrations due to that clay minerals could host REE (Laveuf and Cornu, 2009). The impact of clay, silty and sand fractions on solid REE was recently investigated in different soil profiles (Mihajlovic and Rinklebe, 2018). Presence of Fe/Mn oxides was another factor influencing REE in sediments/soils, and more REE can be accumulated by amorphous Fe/Mn oxides as compared to crystalline ones (Yan et al., 1999; Compton et al., 2003).

Constituents of REE in sediments and soils for a large part result from natural processes. A global distribution pattern of REE in the soils/sediments was recently evaluated by Adeel et al. (2019), which was achieved using spatial visualization of REE concentration distributions in soils/sediments derived from all over the world. Results obtained from the study showed that total REE concentrations of agriculture soils/sediments ranged from 83 to $9840 \mathrm{mg} / \mathrm{kg}$ and concentrations of light REE (LREE) were higher than heavy REE (HREE). This indicates that, in addition to the natural processes, anthropogenic inputs (i.e. fertilizer) contribute to the REE concentrations in sediments/soils in some individual regions. Indeed, fertilization with REE-bearing fertilizers and infiltration of residuals was suggested to be the main mechanism of agriculture-sourced REE entering into soils and sediments (Hu et al., 2004). However, mechanisms for REE mobilization in different soils/sediments and the potential risks of long-term exposure to REE-abundant environment are not adequately understood. 
Average REE concentration in China's soil was established to be $177 \mathrm{mg} / \mathrm{kg}$ (Liang et al., 2005), being comparable to the value (189 mg/kg) of the earth's crust (Wei et al. 1991). China is one of the countries that early widely applied REE in various sectors (Pang et al., 2002; Hu et al., 2006); such as agriculture, the REE have been used as a prompter for crops since 1990s. This has led to high REE pollution levels (i.e. $\mathrm{La}>80 \mathrm{mg} / \mathrm{kg} ; \mathrm{Nd}>85 \mathrm{mg} / \mathrm{kg} ; \mathrm{Sm}>45 \mathrm{mg} / \mathrm{kg}$ ) (Adeel et al., 2019; and references therein). Indeed, sediment and soil contaminations caused by elevated REE have been reported in various regions across China, including in Poyang Lake (Wang et al., 2018), Baotou City (Li et al., 2010), Tibetan Plateau (Wu et al., 2018), Jiaozuo Bay (Zhang and Gao, 2015), Sanjiang Plain (Cheng et al., 2012) and Liaodong Bay (Lin et al., 2013). The North China Plain (NCP) is one of the largest sedimentary basin in Asia (Xing et al., 2013), and is the provincial politics, economy and culture center of China. The plain is characterized by large population ( $>0.35$ billion) and highly-developed agricultural industry, which plays an important role in the nation's grain manufacture (Chen and Ni, 1987; Kendy et al., 2004). The densely-populated and industrialized areas were shown to be accompanied by increased discharge of REE (i.e. Gd and Sm) into environments (Kulaksız and Bau, 2013; Hatje et al., 2016), due to a large amount of REE applied in industry, medicine as well as agriculture. Studies concerning REE concentrations in sediments of the NCP have been performed (Wei et al., 2010; Liu et al., 2016; Zhang and Gao, 2015; Liu et al., 2019a, b), but a full of investigation of mobility, distributions and behaviors of REE in sediments is still lacking. This would hinder a systematical evaluation of REE levels as well as the 
115 possible anthropogenic impact, which is vital for establishing a baseline of 116 distribution and background of REE concentration in the contaminated sediments and

117 for administrating regulation guidelines (Alfaro et al., 2018; Consani et al., 2020).

118 Therefore, the objectives of this study are to: (i) investigate REE concentration and 119 fractionation characteristics in sediments collected from three zones (The zonation 120 was previously specified by Chen et al. (2005)), (ii) characterize the relationships 121 between REE distribution and sediment properties, (iii) assess the feasibility of using 122 REE as a probe of sedimentation process.

\section{Material and methods}

2.1 Study area

The North China Plain (NCP) is located in the eastern China with longitude of $112^{\circ} 30^{\prime} \sim 119^{\circ} 30^{\prime} \mathrm{E}$, and latitude of $34^{\circ} 46^{\prime} \sim 40^{\circ} 25^{\prime} \mathrm{N}$. The terrains are mostly plains with two mountainous regions (Yanshan and Tanghang mountains) bounding to the north and south, and an oceanic region (Bohai Bay) to the east (Chen et al., 1999), respectively. The plain has a total area of approximately $31 \times 10^{4} \mathrm{~km}^{2}$ and population of about 0.35 billion inhabitants. The NCP has a semi-arid humid climate with a temperature range of $-23{ }^{\circ} \mathrm{C} \sim 42.7^{\circ} \mathrm{C}$ (in history). Average annual rainfall ranges from $500 \mathrm{~mm}$ to $600 \mathrm{~mm}$, mostly $(>74 \%)$ dominating in summer. Average annual evaporation is 1.5 to 3 times of annual rainfall. 
stratigraphic areas: Yinshan-Nuruerhu, Yanshan, Taihangshan and Hebei, with ages ranging from the oldest Archaeozoic to the newest Holocene. Formations in study area have been declining since the Cenozoic due to neotectonics. Geographically, the plain generally decreases from the north to the east with a slope of $0.3 \%$ o $0.6 \%$, and thus it's divided into three zones: piedmont alluvial-proluvial plain, central alluvial-lacustrine plain and littoral plain.

Surface sediments in the NCP mainly are Cenozoic deposits with ages from Paleogene to Holocene. Lower Tertiary stratum is composed of red mudstone which is interbeded by red and gay sandstones. Upper Tertiary strata are characterized by consolidated to semi-consolidated alluvial-diluvial deposits, including siltstone, mudstone, sandstone and pebbly sandstone. Quaternary sediments are divided into four groups from top to bottom: Holocene $(\mathrm{Q} 4)$, Upper $\left(\mathrm{Q}_{3} \mathrm{~m}\right)$, Middle $\left(\mathrm{Q}_{2} \mathrm{c}\right)$ and Lower $\left(\mathrm{Q}_{1} \mathrm{n}\right)$ Pleistocene (Chen, 1999). The Holocene sediments group has a thickness of $5 \mathrm{~m}$ to $40 \mathrm{~m}$, and mainly consists of yellow and gray sandy loam, fine sand, clay and sandy gravel. The Upper Pleistocene is alluvial, diluvial and eolian losses and yellow loam. The Middle Pleistocene stratums are widely distributed in intermountain basin and foothills, and consist of red and brown clay, loam and sandy loam, and red mud pebble layers. The Lower Pleistocene sediments group has a buried depth of $350 \mathrm{~m}$ to $500 \mathrm{~m}$ with a thickness of $80 \mathrm{~m}$ to $100 \mathrm{~m}$, and it's mainly loam, sand loam and lenticular sand layers.

Piedmont alluvial-proluvial sediments are suggested to derive from Taihang and Yanshan mountains by weathering, transport and sedimentation process. Central 
alluvial-lacustrine sediments are deposited from materials carried by Yellow River and Zhangweinan River running from SW to NE since middle Pleistocene (Shao et al., 1989). The littoral plain forms with interactions between terrene and ocean, and sedimentary deposits come from terrestrial rivers draining into Bohai Bay.

\subsection{Sediment sampling}

Sediment samples were taken from three boreholes (Y09, S30 and H02) drilled in three different zones (Fig. 1) of the NCP in the July of 2013. The core sediments were sampled with an interval generally ranging between $1 \mathrm{~m}$ and $2 \mathrm{~m}$. Slurries and muds attached on the surface of the core sediments were scrapped off to avoid possible cross contaminations. The samples were parceled with silver paper and were stored in clean plastic bags which were immediately filled with pure $\mathrm{N}_{2}$ gas for a further preservation. All the sealed core sediments were placed in a shaded environment with temperature below $4{ }^{\circ} \mathrm{C}$ during sampling. Finally, the samples were transported to laboratory and preserved in a freezer before analysis.

\subsection{Sediment analysis}

All samples used for major and minor constituents analyses were dried under room temperature in the lab, and were ground to grain size $<74 \mu \mathrm{m}$ with an agate mortar for analysis. The X-ray fluorescence (XRF) (ARL Advant X) technique was used for measurement of various oxides $\left(\mathrm{SiO}_{2}, \mathrm{Fe}_{2} \mathrm{O}_{3}, \mathrm{Al}_{2} \mathrm{O}_{3}, \mathrm{MgO}, \mathrm{CaO}, \mathrm{Na}_{2} \mathrm{O}, \mathrm{K}_{2} \mathrm{O}\right.$, $\mathrm{MnO}, \mathrm{P}_{2} \mathrm{O}_{5}$ and $\mathrm{TiO}_{2}$ ) following the national standard method (GB/T 14506). Sediment samples were prepared with a glass flux sheet method. Specifically, $0.7 \mathrm{~g}$ 
( \pm 0.001 ) sample was first placed in a $25 \mathrm{~mL}$ porcelain crucible; followed by addition of $5.2 \mathrm{~g}( \pm 0.001)$ anhydrous lithium tetraborate, $0.4 \mathrm{~g}( \pm 0.001)$ lithium fluoride and $0.3 \mathrm{~g}( \pm 0.01)$ ammonium nitrate, the mixture was evenly stirred. Then the mixture was transferred to a platinum (95\%)-gold (5\%) alloyed crucible for fusing 10 to 15 mins under temperature 1150 to $1250{ }^{\circ} \mathrm{C}$. Finally, fusant was made into glass beads using a fusion machine. All glass beads were preserved in a clean and dry environment before analysis. Reference materials GSS (shown below) were prepared with the same method for subsequent calibration of XRF. The sample intensity $\left(\mathrm{I}_{\mathrm{S}}\right)$ was calculated by the difference between peak $\left(\mathrm{I}_{\mathrm{p}}\right)$ and background $\left(\mathrm{I}_{\mathrm{b}}\right)$ values, as shown with Eq. (2-1).

$$
\mathrm{I}_{\mathrm{S}}=\mathrm{I}_{\mathrm{p}}-\mathrm{I}_{\mathrm{b}}
$$

Rare earth elements were quantified by employing ICP-MS (AG 7500) with the digested samples. The samples were digested following the method previously described in Liu et al. (2016). Briefly, $9 \mathrm{~mL}$ concentrated $\mathrm{HCl}\left(37 \%\right.$ v/v), $2 \mathrm{~mL} \mathrm{HNO}_{3}$ $(65 \% \mathrm{v} / \mathrm{v})$ and $9 \mathrm{~mL} \mathrm{HF}(40 \% \mathrm{v} / \mathrm{v})$ were used for digesting $0.5 \mathrm{~g}$ dried samples for 24 h under $108{ }^{\circ} \mathrm{C}$ condition. Then the mixture was dried and dissolved again with purified $\mathrm{HNO}_{3}(2 \% \mathrm{v} / \mathrm{v})$. The obtained solutions were used for REE analysis. To check the stability of the equipment system and the analytical accuracy, reference soil sample including GSS1, GSS2, GSS3 and GSS5, obtained from the Center of China National Standard Reference Material, were ran simultaneously. The recommended and test values of REE and metal oxides in standard references were shown in supplementary materials (Table S1). Furthermore, the parallel sample was performed 
every ten samples for further monitoring of the analytical precisions. The results show that elements mostly had accuracies (RSD, $\delta 1$ ) ranging between $2 \%$ and $5 \%$. The standard materials had accuracy generally better than $3 \%$, except for $\mathrm{P}_{2} \mathrm{O}_{5}$, which had an accuracy better than $8 \%$ in some samples. The analytical precisions of REE in all samples were generally better than $5 \%$.

\subsection{REE normalization}

Rare earth element concentrations in all sediment samples were normalized with average REE concentrations of the North American Shale Composite (NASC). The corresponding normalization REE values were taken from Taylor and McLennan (1985). Fractionation between LREE and HREE was quantified using fractionation measures $\left[(\mathrm{La} / \mathrm{Lu})_{\mathrm{NASC}}\right.$ and $\left.\left.(\mathrm{Nd} / \mathrm{Yb})_{\mathrm{NASC}}\right)\right]$. Anomalies including $\mathrm{Ce}\left(\mathrm{Ce} / \mathrm{Ce}{ }^{*}\right)$ and $\mathrm{Eu}$ $\left(\mathrm{Eu} / \mathrm{Eu}^{*}\right)$ were calculated by extrapolation using normalized values of neighboring REE. The corresponding formulas were shown with Eq. (2-1) to (2-4).

$$
\begin{aligned}
& (\mathrm{La} / \mathrm{Lu})_{\mathrm{NASC}}=\left(\mathrm{La}_{\text {sample }} / \mathrm{La}_{\mathrm{NASC}}\right) /\left(\mathrm{Lu}_{\text {sample }} / \mathrm{Lu}_{\mathrm{NASC}}\right) \\
& (\mathrm{Nd} / \mathrm{Yb})_{\text {NASC }}=\left(\mathrm{Nd}_{\text {sample }} / \mathrm{Nd}_{\mathrm{NASC}}\right) /\left(\mathrm{Yb}_{\text {sample }} / \mathrm{Yb}_{\mathrm{NASC}}\right) \\
& \mathrm{Ce} / \mathrm{Ce}{ }^{*}=\mathrm{Ce}_{\text {NASC }} /\left(\mathrm{La}_{\text {NASC }} \times \mathrm{Pr}_{\text {NASC }}\right)^{0.5} \\
& \mathrm{Eu} / \mathrm{Eu}^{*}=\mathrm{Eu}_{\mathrm{NASC}} /\left(\mathrm{Sm}_{\mathrm{NASC}} \times \mathrm{Gd}_{\mathrm{NASC}}\right)^{0.5}
\end{aligned}
$$

where the superscript $*$ indicates the geogenic background.

\subsection{Calculation of mass transfer coefficient}

To evaluate REE mobility, the mass transfer coefficient $(\tau)$ was calculated by the

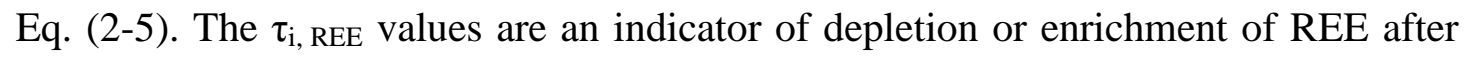


normalization against reference element $\mathrm{i}$ in standard materials (NASC for this study). Positive $\tau_{i, \text { REE }}$ values mean enrichment of REE (total or individual) in the sediments (s) with respect to NASC; negative values indicate depletion and zero indicate REE are immobile. Elements include $\mathrm{Fe}, \mathrm{Al}, \mathrm{Mn}, \mathrm{Ti}$, and $\mathrm{Ca}$ can be used as reference element $i$. This study chooses $\mathrm{Ti}$ as the reference because it has been used previously (Wu et al., 2018).

$$
\tau_{\mathrm{i}, \mathrm{REE}}=\left(\mathrm{C}_{\mathrm{REE}} / \mathrm{C}_{\mathrm{i}}\right)_{\mathrm{sample}} /\left(\mathrm{C}_{\mathrm{REE}} / \mathrm{C}_{\mathrm{i}}\right)_{\mathrm{NASC}}-1
$$

\section{Results and discussion}

\subsection{Sediment geochemistry and provenance}

Sediment lithology in three boreholes were mainly clay, silt and silty clay (Fig. 2). Fine and course sands were generally interbedded with silt and silty clay at different sampling depths. This was well observed in the central (S30) and littoral (H02) borehole bar graphs (Figs. 2b and c). In piedmont borehole, a gravel layer occurred at depth between $38 \mathrm{~m}$ and $61 \mathrm{~m}$ (Fig. 2a). Gravel was not found in boreholes S30 and HH02. Overall, fine grains prevailed in central and littoral sediment samples. Colors of the fine grains changed in three zones as well. Pale yellow and pale brownish-yellow clay and silty were mainly distributed in piedmont sediments. For central borehole sediments, the color changed from pale brownish-yellow to brown and tan vertically. For littoral sediments, taupe and tawny silty and silty clay were mainly in upper and middle parts, and pale brownish-yellow and pale brown in lower part (Fig. 2c). 
piedmont sediments (borehole Y09), contents (wt\%) of $\mathrm{SiO}_{2}$ ranged from 55.55 to 78.36 with an average value of 66.77. Central (borehole S30) and littoral (borehole HH02) sediments had $\mathrm{SiO}_{2}$ contents (wt \%) lower than those of piedmont, being in the ranges of 35.71 to 71.56 (average 56.62) and 32.04 to 77.03 (average 59.51), respectively. Aluminum oxide $\left(\mathrm{Al}_{2} \mathrm{O}_{3}\right)$ had the highest contents among the determined metal oxides, with ranges of 6.37 to $14.14 \mathrm{wt} \%, 7.42$ to $13.82 \mathrm{wt} \%$ and 7.32 to 15.95 wt $\%$ and average values of $10.47 \mathrm{wt} \%, 10.95 \mathrm{wt} \%$ and $12.18 \mathrm{wt} \%$ in piedmont, central and littoral sediments, respectively. Iron oxide $\left(\mathrm{Fe}_{2} \mathrm{O}_{3}\right)$ was the second abundant metal oxides, with a range from $1.86 \mathrm{wt} \%$ to $9.86 \mathrm{wt} \%$ and an average of $5.46 \mathrm{wt} \%$ in piedmont sediments. The average content $(\mathrm{wt} \%)$ of $\mathrm{Fe}_{2} \mathrm{O}_{3}$ in central and littoral sediments was $4.45 \mathrm{wt} \%$ and $4.06 \mathrm{wt} \%$, respectively, exhibiting slightly lower than that of piedmont sediments. Other metal oxides including $\mathrm{Na}_{2} \mathrm{O}, \mathrm{K}_{2} \mathrm{O}, \mathrm{CaO}$, $\mathrm{MgO}, \mathrm{P}_{2} \mathrm{O}_{5}$ and $\mathrm{TiO}_{2}$ showed relatively lower content in most of the measured sediment samples as compared to $\mathrm{SiO}_{2}$ and $\mathrm{Al}_{2} \mathrm{O}_{3}$ (Table 1). Average value (wt $\%$ ) of loss on ignition (LOI) was 3.88, 8.56 and 8.02 in piedmont, central and littoral zones with ranges of 1.13 to $7.36,3.12$ to 19.91 and 2.5 to 17.56 , respectively.

Changes of sediment lithology were controlled by the sedimentary provenances and processes (Bhuiyan et al., 2011; Blake et al., 2017). This would account for that sediments were deposited alternately with clay, silty clay and fine sand (Fig. 2). Terrigenous clastic deposition and land-ocean interactions led to the formation of littoral sedimentation. Weathering and erosion of the bedrocks around the piedmont plain and subsequent transport and sedimentation contributed to the NCP sediments. 
Ternary diagram of sandstone classification (Blatt et al., 1980) showed that the majority of sediment samples were located in the greywacke domain, and three central samples in the arkose domain indicating that sediments originally mostly were greywacke (Fig. 3a). The dominant $\mathrm{SiO}_{2}$ contents and fine-grained components reflected that the sedimentary materials had been undergone intensive denudations and a long-distance transport before sink. Indeed, the ternary diagram of $\mathrm{Al}_{2} \mathrm{O}_{3}-\mathrm{CaO}+\mathrm{Na}_{2} \mathrm{O}-\mathrm{K}_{2} \mathrm{O}(\mathrm{A}-\mathrm{CN}-\mathrm{K})$ showed that the weathering trend of the sediment samples were mostly along the axis of $\left(\mathrm{CaO}+\mathrm{Na}_{2} \mathrm{O}\right)$ (Fig. 3b). This probably indicated that sediment samples from the NCP were in an early weathering stage where minerals such as plagioclase was incongruently decomposed in association with leaching of $\mathrm{Na}$ and $\mathrm{Ca}$ generating products of illite, kaolinite and smectite (Nesbitt et al., 1980). The offset to the uppermost of $\mathrm{K}_{2} \mathrm{O}$ axis was attributed to the addition of terrigenous detrital in the later sedimentary stage (Cox et a1., 1995).

To quantify the weathering intensity in different samples, the chemical index of alteration (CIA) values (initially was valid for granitic rocks) were calculated following the method proposed by Nesbitt and Young (1982) $\left[\mathrm{CIA}=\left(\mathrm{Al}_{2} \mathrm{O}_{3} /\left(\mathrm{Al}_{2} \mathrm{O}_{3}+\right.\right.\right.$ $\left.\left.\mathrm{K}_{2} \mathrm{O}+\mathrm{Na}_{2} \mathrm{O}+\mathrm{CaO}^{*}\right)\right) \times 100 ; \mathrm{CaO}^{*}=\left[\mathrm{CaO}-\left(10 / 3 \times \mathrm{P}_{2} \mathrm{O}_{5}\right)(\right.$ Panahi et al., 2000) $]$. Chemical index of alteration can be an index reflecting sample in a weathering trend from fresh status to intensely-altered status. Granites and granodiorites usually have CIA values ranging from 45 to 50, and fresh basalts have values between 30 and 45 . Muscovite has a value of 75 , and illite, montmorillonites and beidellites give values from 75 to 85 (Nesbitt and Young, 1982). Results showed that CIA value of piedmont 
sediment samples ranged from 55 to 78 with an average value of 68 , and central and littoral samples ranged from 37 to 70 (average 51), and from 43 to 70 (average 55), respectively. This indicates that sediment samples were incipiently (CIA: 50 to 60) to intermediately (CIA: 60 to 80 ) chemically weathered, according to the classification standards suggested by Fedo et al. (1995). It's also observed that piedmont sediment samples generally had higher CIA values as compared to those of central and littoral sediments, which means a stronger weathering may have occurred in the piedmont sediment samples. These differences probably were associated with the hydrogeological conditions such as REE residence time, outcrop lithology and aquifer replenishment conditions (Condie, 1991; Blake et al., 2017). The results were consistent with piedmont samples being located in the upper part of the A-CN-K diagram, while central and littoral sediment samples below the piedmont samples (Fig. 3b). The role of chemical weathering on sedimentary processes was studied previously based on sediment geochemical compositions (LaMaskin et a1., 2008; Dostal and Keppie, 2009; Xie et al., 2014). Combined to studies of the residence time of REE (Condie, 1991), it's accepted that REE fingerprinting in sediment could serve as a good proxy for understanding the origins and processes of sedimentation, as shown in this investigation.

3.2 REE distribution characteristics

\subsubsection{REE concentrations}

Total REE ( REE) concentrations were shown in Table 1. Piedmont sediment 
(borehole Y09) $\Sigma$ REE ranged from $190 \mathrm{mg} / \mathrm{kg}$ to $354 \mathrm{mg} / \mathrm{kg}$ with an average value of $227 \mathrm{mg} / \mathrm{kg}$. Sediments from central (borehole S30) and littoral (borehole H02) zones had $\Sigma$ REE concentrations ranging from $89 \mathrm{mg} / \mathrm{kg}$ to $291 \mathrm{mg} / \mathrm{kg}$ (average $183 \mathrm{mg} / \mathrm{kg}$ ) and from $87.90 \mathrm{mg} / \mathrm{kg}$ to $238 \mathrm{mg} / \mathrm{kg}$ (average $177 \mathrm{mg} / \mathrm{kg}$ ), respectively. Generally, sediment $\Sigma$ REE concentrations showed a decreasing trend (piedmont > central > littoral) along a groundwater flow direction. The average $\Sigma$ REE concentrations in littoral sediment samples from study area were comparable to the values of Upper Continental Crust (UCC) (169 mg/kg) (McLennan, 2001) and Chinese soil (177 $\mathrm{mg} / \mathrm{kg}$ ) (Wei et al., 1991); while average $\Sigma$ REE concentrations of piedmont and central sediments were higher than the values of UCC and soil in China, showing a spatial disparity. All measured average REE concentrations were within in the levels (166 mg/kg to $222 \mathrm{mg} / \mathrm{kg}$ ) reported in similar researches performed in the same study area (Lan et al., 2016). Others showed that core sediment $\Sigma$ REE concentrations were slightly higher than the value of surface sediment (Liu et al., 2019b).

Sediment $\Sigma$ REE concentrations varied along depth. In the piedmont borehole, ¿REE concentrations were relatively constant within $11 \mathrm{~m}$ below land surface. A small decrease in $\mathrm{R} E E$ concentrations was observed at depth from $11 \mathrm{~m}$ to $16 \mathrm{~m}$ before they increased to $>300 \mathrm{mg} / \mathrm{kg}$ at $25 \mathrm{~m}$. After a new decrease to about $63 \mathrm{~m}$, ¿REE concentrations fluctuated for the remaining sampling depths (Fig. 2a). $\Sigma$ REE concentrations in central sediments were highly variable along borehole, although a decreasing trend occurred from land surface to $30 \mathrm{~m}$. Vertical changes of $\mathrm{R}$ REE concentrations were mainly related to sediment physicochemical properties (Kimoto 
et al., 2006; Mihajlovic and Rinklebe, 2018). Sediments with different grain sizes, such as clay, silt and silty clay, had different capacities in hosting REE. The major minerals in the aquifer sediments of study area were shown to be quartz, K-feldspar, hornblende and calcite accounting for 5\%-14\% in the piedmont (Chen and $\mathrm{Ni}, 1987$ ). Clay minerals (i.e. kaolinite, illite and montmorillonite) were more commonly distributed in the central and littoral plains as compared to the piedmont plain (Chen et al., 2005). In the piedmont, where fine sand prevailed (i.e. from $38 \mathrm{~m}$ to $62 \mathrm{~m}$ ), $\Sigma$ REE concentrations progressively decreased (Fig. 2a). Low $\Sigma$ REE concentrations of central sediments were found at depth of approximately $30 \mathrm{~m}, 65 \mathrm{~m}$ to $68 \mathrm{~m}, 107 \mathrm{~m}$, $151 \mathrm{~m}$ to $154 \mathrm{~m}$, where fine sands were sandwiched with silt and silty clay (Fig. 2b). Silt sand and fine sand more commonly occurred at deeper depth, leading to a decreasing trend of $\Sigma$ REE concentrations (Fig. 2c). This demonstrated that presence of clay was one of factors controlling $\Sigma$ REE concentrations. Lanthanides were thought to be hosted by clay component containing in the sediments (Yang et al., 2002). The disparities of clay content along depth for a large part accounted for REE variations along depth. This was supported by the vertical variations of $\mathrm{Si} / \mathrm{Al}$ values, which were proxies for grain size classification (i.e. clay, silt, and silty clay) (Fig. S2). Statistical analyses showed that $\Sigma$ REE concentrations were negatively correlated to $\mathrm{SiO}_{2}$ and were significantly positively correlated to $\mathrm{Fe}_{2} \mathrm{O}_{3}$ and $\mathrm{Al}_{2} \mathrm{O}_{3}$ (except for littoral sediment samples) (Table 2), reflecting that REE mainly adsorbed onto/incorporated into $\mathrm{Fe}$ and Al-containing clay minerals. Normalization of REE to Ti showed that $\tau_{\mathrm{i}, \text { REE }}$ values mostly changed slightly, and generally were positive for 
piedmont sediments and negative for central and littoral sediment. This suggested that dilution of weathered residuals (i.e. $\mathrm{SiO}_{2}$ ) did not significantly modify REE concentrations in sediment samples. Moreover, trends of $\mathrm{SiO}_{2} / \mathrm{Al}_{2} \mathrm{O}_{3}$ values were generally consistent with those of CIA, suggesting that weathering of silicates like feldspar played a role in this process (Fig. 2). In other words, in addition to clay content, $\mathrm{Fe}$ and Al-bearing oxides could be another factor influencing REE concentrations in investigated sediment samples. Therefore, mixture of clay minerals and Fe-Mn oxides accounted for normalized REE values. Metal oxides containing Fe, Mn and Al provide important binding sites for sorption of REE (Ohta and Kawabe, 2000; Pourret and Davranche, 2013; Liu et al., 2017; Mihajlovic et al., 2019). These findings are in line with the results documented by Wang et al. (2014), showing that fine fractions with abundant clay minerals and $\mathrm{Fe} / \mathrm{Al} / \mathrm{Mn}$-containing oxides tended to accumulate REE, while coarse fractions with less clay minerals and more quartz led to less REE contents. However, further information on mineralogical compositions of sediment samples is needed for better constraining the impact of mineralogy on REE concentrations from a quantitative perspective. In all, sediment REE concentrations were essentially regulated by their genetic properties and were revealed by their vertical variations.

\subsubsection{REE fractionation patterns}

All sediment samples had relatively flat NASC-normalized REE patterns with a gentle enrichment of LREE over HREE (Fig. 4). The degree of LREE enrichment was quantified by $(\mathrm{La} / \mathrm{Yb})_{\mathrm{NASC}}$ values, which ranged between 0.86 and 1.15 with an 
average of 1.23 in piedmont sediments. Central and littoral sediment samples had $(\mathrm{La} / \mathrm{Yb})_{\mathrm{NASC}}$ ranges of 1.03 to 1.14 (average 1.21 ) and 0.91 to 1.49 (average 1.09), respectively (Table 1). Sediments mostly showed negative $\mathrm{Ce}$ anomalies with $\mathrm{Ce} / \mathrm{Ce}$ * ranging between 0.69 and 1.17 (average 0.91 ), and between 0.85 and 0.98 (average 0.90 ), and between 0.80 and 0.98 (average 0.89 ) in piedmont, central and littoral plains, respectively. Negative Eu anomalies commonly occurred in investigated sediments with $\mathrm{Eu} / \mathrm{Eu}^{*}$ ranges of 0.82 to 1.07 (average 0.91 ), 0.83 to 1.31 (average 0.95 ), and 0.86 to 1.34 (average 0.95 ) in three zones, respectively. Correlation analysis indicated that $\Sigma$ REE concentrations generally increased with an increase of $(\mathrm{La} / \mathrm{Yb})_{\mathrm{NASC}}$ in piedmont and central sediments, while this trend was not observed in littoral sediment samples (Fig. 5a). These results reflected REE were nonuniformly accumulated by sediments during their transport. The correlation between $(\mathrm{La} / \mathrm{Yb})_{\mathrm{NASC}}$ and CIA values showed that the larger $(\mathrm{La} / \mathrm{Yb})_{\mathrm{NASC}}$ values occurred in samples containing higher $\Sigma$ REE concentrations and generally having higher CIA values (Fig. 5b). Thus, LREE enrichments could result from the chemical weathering of silicates in crustal materials, which led to higher levels of LREE in sediments (Oliveira et al., 2003; Lin et al., 2013). Larger CIA values were obtained from piedmont and central zones as compared to the values in littoral zones (shown above). The different domains of littoral sediment samples from their piedmont and central counterparts might be related to impact of ocean and/or human activities. However, more studies are needed to verify this speculation.

Sediment samples mostly had negative Eu anomalies (Fig. S2). Average Eu/Eu* 
anomalies were quite similar in three different zones. This indicated that sedimentary processes, which evolved weathering of bedrocks around plains and migration and deposition in the flat plains, did not fractionate Eu to a larger extend with respect to its neighboring Sm and Gd. Early investigations demonstrated that Eu compositions and distributions in continental crust were fundamentally controlled by shallow, intracrustal differentiation involving Eu-bearing minerals (i.e. plagioclase) (McLennan, 2001), which was shown to possess $4 \%$ to $23 \%$ (wt) in piedmont sediments (Liu et al., 2016). However, Eu/Eu* values were negatively correlated to $\Sigma$ REE concentrations (Fig. 5d), suggesting that evolution of Eu anomalies was related to changes of redox conditions as well during sedimentation. Preferential mobilization of Eu(II) over other trivalent REE leads to a segregation of Eu from lanthanide series under reducing conditions (Lee et al., 2003), and hence higher $\Sigma$ REE concentrations occur in lower-Eu/Eu* samples, as shown in Figure $5 \mathrm{~d}$. This mechanism has been proposed for using Eu anomalies as an indicator for investigating REE origins as well as mobility of redox-sensitive metal(oid) (Guo et al., 2010; Davranche et al., 2011). Another possibility resulting in negative correlation between Eu anomalies and $\mathrm{REE}$ concentrations would be related to minerals contained in sediments. Such as plagioclase, which tends to preferentially accumulate $\mathrm{Eu}(\mathrm{II})$ over trivalent REE by means of isomorphism with $\mathrm{Ca}^{2+}, \mathrm{Na}^{+}$and $\mathrm{K}^{+}$(Banks et al., 1999).

Cerium anomalies $\left(\mathrm{Ce} / \mathrm{Ce}^{*}\right)$ were relatively constant in central and littoral sediments despite variable $\Sigma$ REE concentrations, while they were distributed scattered as a function of $\Sigma$ REE concentrations in piedmont sediment samples (Fig. S2). The 
414 fluctuation of redox conditions could account for this phenomenon due to fact that $\mathrm{Ce}$

415 is readily to be precipitated as insoluble $\mathrm{Ce}(\mathrm{IV})$ via oxidative scavenging, and when

416 conditions evolve into reducing, the precipitated Ce will be released into solution by

417 reductive dissolutions (Bau and Koschinsky, 2009; Steinmann and Stille, 2008).

418 Cerium cycle was believed to be biologically mediated (Moffett, 1990; Tanaka et al.,

419 2010) and involved metal (i.e. Fe, Mn) oxides (Yu et al., 2017). Results of our recent

420 study showed that Ce precipitation from oxic aqueous solution was more likely to

421 occur in the piedmont aquifers where low-Fe/Mn-concentration groundwater

422 prevailed (Liu et al., 2019a), though no pronounced positive Ce anomalies were

423 commonly observed in the piedmont aquifer sediments. Thus, both positive and

424 negative $\mathrm{Ce}$ anomalies, and no Ce anomalies can be found in solid phases in nature, as

425 the results shown in present study.

\subsection{Implication for REE signatures}

Statistical analyses showed that individual REE concentrations were significantly correlated with correlation coefficient $\left(\mathrm{R}^{2}\right)$ all better than 0.8 . These results, together with the findings that all investigated sediment samples had coherent normalized patterns, indicated that sediments had similar sources/inputs of REE as well as common geochemistry. The remarkable uniformity of sedimentary REE patterns, with absolute concentration ranging from $\mathrm{La}$ to $\mathrm{Lu}$, slight LREE enrichment and common negative Eu anomalies, implied that REE were migrated and transported as an integral whole during chemical weathering and sedimentation processes including erosion, 
patterns suggested that REE information recorded in sediments could serve as an ideal tool for studying crustal evolution and sedimentary provenance. The higher REE abundances in sediment than the values of UCC reflected that an enrichment of REE occurred during the process of sedimentation. Since sedimentary REE uniformity was thought to result from effective mixing of various provenance components from the upper crust (McLennan, 2001) and they were transported primarily in particulates, the sedimentary origins and secondary mobilization would be the plausible cause for higher REE abundance. It should be noted that, in addition to natural processes, REE can be accumulated in sediments and soils by various ways including sewage discharges (Verplanck et al., 2005; Hatje et al., 2016), agricultural activities (Alfaro et al., 2018) and atmospheric depositions (Tyler, 2004), although the investigated sediments were unlikely to suffer from these anthropogenic pollutions due to that most of them were not formed nowadays. Positive REE anomalies will show up in REE normalized patterns when individual elemental concentration is greater than its background value, such as Gd anomalies, which have been reported worldwide (Ebrahimi and Barbieri, 2019; and references therein). In summary, sedimentary REE patterns conveys important information regarding the composition of the continental crust and anthropogenic impact.

\section{Conclusions}

The 226 sediment samples were collected from three different zones (i.e. piedmont, central and littoral) of the north China plain to investigate the concentrations and fractionations of rare earth element (REE). Sediment geochemistry 
indicated that sediments mostly were derived from greywacke, as suggested by triangular diagram of sandstone classification. All sediment samples had been undergone incipient to intermediate weathering with average CIA of 68,51 and 55 in three zones, respectively. Total REE concentrations ranged from 190.24 to 353.87 $\mathrm{mg} / \mathrm{kg}$ (average $228.62 \mathrm{mg} / \mathrm{kg}$ ), and from 88.85 to $290.80 \mathrm{mg} / \mathrm{kg}$ (average 182.88 $\mathrm{mg} / \mathrm{kg}$ ), and from 87.90 to $237.61 \mathrm{mg} / \mathrm{kg}$ (average $176.69 \mathrm{mg} / \mathrm{kg}$ ) in piedmont, central and littoral plains, exhibiting a decreasing trend as piedmont $>$ central > littoral. Sediment physicochemical properties such as mineral composites and metal oxide abundance controlled REE concentrations, as observed along depth in three sediment sampling profiles. All sediment samples had coherent NASC-normalized REE patterns that were characterized by light REE (LREE) enrichment over heavy REE (HREE) with $(\mathrm{La} / \mathrm{Yb})_{\mathrm{NASC}}$ ranging between 0.86 and 1.49 . Negative $\mathrm{Ce}$ and $\mathrm{Eu}$ anomalies generally occurred in the investigated sediments with $\mathrm{Ce} / \mathrm{Ce} *$ and $\mathrm{Eu} / \mathrm{Eu}^{*}$ ranges of 0.69 to 1.17 and 0.82 to 1.34 , respectively. The present study provides important dataset for future comparative studies in this region.

\section{Acknowledgments}

This investigation has been funded by National Natural Science Foundation of China (Nos. 41902243, 41222020 and 41172224), National Natural Science Foundation of Jiangxi Province, China (20202BABL211018), the program of China Geology Survey (No. 12120113103700), and the Fok Ying-Tung Education Foundation, China (Grant No. 131017). East China University of Technology Research Foundation for Advanced Talents (Nos. DHBK2019094 and SHT201901). 


\section{References}

Adeel, M., Lee, J. Y., Zain, M., Rizwan, M., Nawab, A., Ahmad, M. A., Shafiq, M., Yi, H., Jilani, G., Javed, R., Horton, R., Rui, Y. K., C. W. Tsangk, D. and Xing, B. S., (2019) Cryptic footprints of rare earth elements on natural resources and living organisms. Environ. Int. 127, 785-800.

Alfaro, M. R., Araújo doNascimento, C. W., Miranda Biondi, C., da Silva, Y. J. A. B., de AguiarAccioly, A. M., Montero, A., Ugarte, O. M. and Esteveze, J. (2018) Rare-earth-element geochemistry in soils developed in different geological settings of Cuba. Catena 162, 317-324.

Banks, D., Hall, G., Reimanna, C. and Siewers, U. (1999). Distribution of rare earth elements in crystalline bedrock groundwaters: Oslo and Bergen regions, Norway. Appl. Geochem. 14, 27-39.

Bau, M. and Koschinsky, A. (2009) Oxidative scavenging of cerium on hydrous Fe oxide: Evidence from the distribution of rare earth elements and yttrium between Fe oxides and Mn oxides in hydrogenetic ferromanganese crusts. Geochem. J. 43, $37-47$.

Bhuiyan, M. A. H., Rhaman, M. J. J., Dampare, S. B., Suzuki, S. (2011) Provenance, tectonics, and source weathering of modern fluvial sediments of the Brahmaputra-Jamuna River, Bangladesh: inference from geochemistry. J. Geochem. Explor. 111, 113-137.

Blake, J. M., Peters, S. C., Johannesson, K. H. (2017) Application of REE geochemical signatures for Mesozoic sediment provenance to the Gettysburg 
Blatt, H., Middleton, G. V. and Murray, R. C. (1980) Origin of Sedimentary Rocks (2nd edition). New Jersey: Prentice-Hall, 1-634.

Chen, W. H. and Ni, M. Y. (1987) Quaternary Geology in Hebei. Geological Publish House, Beijing, China. (In Chinese).

Chen, W. H. (1999) Groundwater in Hebei. Seismological Press, Beijing, (In 
Cox, R., Lowe, D. R. and Cullers, R. L. (1995) The influence of sediment recycling and basement composition on evolution of mudrock chemistry in the southwestern United States. Geochim. Cosmochim. Acta 59(14), 2919-29440.

Davranche, M., Grybos, M., Gruau, G., Pédrot, M., Dia, A. and Marsac, R. (2011) Rare earth element patterns: a tool for identifying trace metal sources during wetland soil reduction. Chem. Geol. 284(1-2), 0-137.

Dostal, J. and Keppie, J. D. (2009) Geochemistry of low-grade ctastic rocks in the Acatl An Complex of southern Mexico: Evidence for local provenance in felsie-intermediate igneous rocks. Sediment. Geol. 222(3-4), 241-253.

Ebrahimi, P. and Barbieri, M. (2019) Gadolinium as an emerging microcontaminant in water resources: threats and opportunities. Geosciences (Switzerland) 9(2), 93.

Fedo, C. M., Nesbitt, H. W., Young and G. M. (1995) Unraveling the effects of potassium metasomatism in sedimentary rocks and paleosols with implications for paleoweathering conditions and provenance. Geology 23, 921-924.

GB/T 14506. (2010). Methods for chemical analysis of silicate rocks.

Guo, H. M., Zhang, B., Wang, G. C. and Shen, Z. L. (2010) Geochemical controls on arsenic and rare earth elements approximately along a groundwater flow path in the shallow aquifer of the Hetao Basin, Inner Mongolia. Chem. Geol. 270, 117-125.

Han, G. L., Song, Z. L. and Tang, Y. (2017) Geochemistry of rare earth elements in soils under different land uses in a typical karst area, Guizhou Province, Southwest China. Can. J. Soil Sci. 97, 606-612. 
Hatje, V., Bruland, K. W. and Flegal, A. R. (2016) Increases in anthropogenic gadolinium anomalies and rare earth element concentrations in San Francisco Bay over a twenty-year record. Environ. Sci. Technol. 50, 4159-4168.

Henderson, P. (1984) Rare earth element geochemistry, Elsevier, Amsterdam.

Hu, Z., Richter, H., Sparovek, G. and Schnug, E. (2004) Physiological and biochemical effects of rare earth elements on plants and their agricultural significance: a review. J. Plant Nutr. 27, 183-220.

Hu, Z. Y., Haneklaus, S., Sparovek, G. and Schnug, E. (2006) Rare earth elements in soils. Commun. Soil Sci. Plant 37(9-10), 1381-1420.

Kendy, E., Zhang, Y., Liu, C., Wang, J. and Steenhuis, T. (2004) Groundwater recharge from irrigated cropland in the North China Plain: case study of Luancheng County, Hebei Province, 1949-2000. Hydrol. Process. 18(12), 2289-2302.

Kimoto, A., Nearing, M. A., Zhang, X. C. and Powell, D. M. (2006) Applicability of rare earth element oxides as a sediment tracer for coarse-textured soils. Catena 65 (3), 214-221.

Kulaksiz, S. and Bau, M. (2013) Anthropogenic dissolved and colloid/nanoparticle-bound samarium, lanthanum and gadolinium in the Rhine River and the impending destruction of the natural rare earth element distribution in rivers. Earth Planet Sc. Lett. 362, 43-50.

LaMaskin, T. A., Dorsey, R. J. and Vervoort, J. D. (2008) Tectonic controls on mudrock geochemistry Mesozoic rocks of eastern Oregon and western Idaho. 
Lan, X. H., Li, R. H., Mi, B. B., Zhang, Z. X., Guo, X. W. and Long, H. (2016) Distribution characteristics of rare earth elements in surface sediment and their provenance discrimination in the eastern Bohai and northern Yellow Seas. Earth Sci. 41(3), 462. (In Chinese with English abstract).

Laveuf, C. and Cornu, S. (2009) A review on the potentiality of rare earth elements to trace pedogenetic processes. Geoderma 154, 1-12.

Lee, S. G., Lee, D. H., Kim, Y., Chae, B. G., Kim, W. Y. and Woo, N. C. (2003) Rare earth elements as indicators of groundwater environment changes in a fractured rock system: evidence from fracture-filling calcite. Appl. Geochem. 18, 135-143.

Li, J., Hong, M., Yin, X. and Liu, J. (2010) Effects of the accumulation of the rare earth elements on soil macrofauna community. J. Rare Earth 28, 957-964.

Liang, T., Zhang, S., Wang, L. J., Kung, H. T., Wang, Y. Q., Hu, A. T. and Ding, S. M., (2005) Environmental biogeochemical behaviors of rare earth elements in soil-plant systems. Environ. Geochem. Health 27, 301-311.

Lin, C. Y., Liu, S. Q., He, M. C. and Li, R. P. (2013) Distribution of rare earth elements in the estuarine and coastal sediments of the daliao river system, China. J. Radioanal. Nucl. Ch. 298(1), 627-634.

Liu, H. Y., Guo, H. M., Xing, L. N., Zhan, Y. H., Li, F. L., Shao, J. L., N, H., L, X. and Li, C.Q. (2016) Geochemical behaviors of rare earth elements in groundwater along a flow path in the North China Plain. J. Asian Earth Sci. 117, $33-51$. 
Liu, H. Y, Pourret, O., Guo, H. M. and Bonhoure, J. (2017) Rare earth elements sorption to iron oxyhydroxide: Model development and application to groundwater. Appl. Geochem. 87, 158-166.

Liu, H. Y., Guo, H. M., Pourret O., Chen, Y. and Yuan, R. X. (2019a) Role of manganese oxyhydroxides in the transport of rare earth elements along a groundwater flow path. Int. J. Environ. Res. Public Health 16, 2263.

Liu, J., Song, J. M., Yuan, H. M., Li, X. G., Li, N. and Duan, L. Q. (2019b) Rare earth element and yttrium geochemistry in sinking particles and sediments of the Jiaozhou Bay, North China: Potential proxy assessment for sediment resuspension. Mar. Pollut. Bull. 144, 79-91.

McLennan, S. M. (1989) Rare earth elements in sedimentary rocks: Influence of provenance and sedimentary processes. Rev. Mineral. Geochem. 21, 169-200.

McLennan, S. M. (2001) Relationships between the trace element composition of sedimentary rocks and upper continental crust. Geochemistry, Geophysics, Geosystems, 2(4).

Mihajlovic, J. and Rinklebe, J. (2018) Rare earth elements in German soils-A review. Chemosphere 205(AUG), 514-523.

Mihajlovic, J., Bauriegel, A., Stärk, H. J., Roßkopf, N., Zeitz, J., Milbert, G. and Rinklebe, J. (2019) Rare earth elements in soil profiles of various ecosystems across Germany. Appl. Geochem. 102, 197-217.

Moffett, J. W. (1990) Microbially mediated cerium oxidation in seawater. Nature 345, 421-423. 
612

613

614

615

616

617

618

619

620

621

622

623

624

625

626

627

628

629

630

631

632

633

Nesbitt, H. W., Markovics, G. and Price, R. C. (1980) Chemical processes affecting alkalis and alkaline earths during continental weathering. Geochim. Cosmochim. Acta 44 (11), 1659-1666.

Nesbitt, H. W. and Young, G. M. (1982) Early Proterozoic climates and plate motions inferred from major chemistry of lutites. Nature, 299, 19-40.

Ohta, A. and Kawabe, I. (2000) Rare earth element partitioning between Fe oxyhydroxide precipitates and aqueous $\mathrm{NaCl}$ solutions doped with $\mathrm{NaHCO}_{3}$ : Determinations of rare earth element complexation constants with carbonate ions. Geochem. J. 34, 439-454.

Oliveira, S. M. B., Larizzatti, F. E., Fávaro, D. I. T., Moreira, S. R. D., Mazzilli, B. P. and Piovano, E. L. (2003) Rare earth element patterns in lake sediments as studied by neutron activation analysis. J. Radioanal. Nucl. Ch. 258, 531-535.

Panahi, A., Young, G. M and Rainbird, R. H. (2000) Behavior of major and trace elements (including REE) during Paleoproterozoic pedogenesis and diagenetic alteration of an Arehean granite near Ville Marie, Québee, Canada. Geochim. Cosmochim. Acta 64(13), 2199-2220.

Pang, X., Li, D. and Peng, A. (2002) Application of rare-earth elements in the agriculture of China and its environmental behavior in soil. Environ. Sci. Pollut. Res. 9, 143-148.

Pourret, O. and Davranche, M. (2013) Rare earth element sorption onto hydrous manganese oxide: A modeling study. J. Colloid Interf. Sci. 395, 18-23.

Pourret, O. and Tuduri, J. (2017) Continental shelves as potential resource of rare 
earth elements. Sci. Rep. 7, 585.

Pédrot, M., Dia, A., Davranche, M. and Gruau, G. (2015) Upper soil horizons control the rare earth element patterns in shallow groundwater. Geoderma, 239-240, 84-96.

Salmanighabeshi, S., Palomo-Marín, M. R., Bernalte, E., Rueda-Holgado, F., Miró-Rodríguez, C., Fadic-Ruiz, X., Vidal-Cortez, V., Cereceda-Balic, F., Pinilla-Gil, E. (2015). Long-term assessment of ecological risk from deposition of elemental pollutants in the vicinity of the industrial area of Puchuncaví-Ventanas, central Chile. Sci Total Environ 527-528: 335-43.

Sá Paye, H., de, Mello, J. W. V., de, Magalhães Mascarenhas, G. R. L., de and Gasparon, M. (2016) Distribution and fractionation of the rare earth elements in Brazilian soils. J. Geochem. Explor. 161, 27-41.

Shao, S. X., Guo, S. Q. and Han, S. H. (1989) Geomorphical structures and evolution of the Huanghuaihai plain in China. Acta Geosicien. Sin. 44(3), 314-322.

Silva, Y. J. A. B., Cantalice, J. R. B., Singh, V. P., Nascimento, C. W. A., Piscoya, V. C. and Guerra, S. M. S. (2015) Trace element fluxes in sediments of an environmentally impacted. Environ. Sci. Pollut. Res. 22, 14755-14766.

Steinmann, M. and Stille, P. (2008) Controls on transport and fractionation of the rare earth elements in stream water of a mixed basaltic-granitic catchment basin (Massif Central, France). Chem. Geol. 254(1), 1-18.

Šmuc, N. R., Dolenec, T., Serafimovski, T., Dolenec, M. and Vrhovnik, P. (2012) Geochemical characteristics of rare earth elements (REEs) in the paddy soil and 

rice (Oryza sativa L.) system of Kočani Field, Republic of Macedonia. Geoderma, 183-184, 1-11.

Tanaka, K., Tani, Y., Takahashi, Y., Tanimizu, M., Suzuki, Y., Kozai, N. and Ohnuki, T. (2010) A specific Ce oxidation process during sorption of rare earth elements on biogenic Mn oxide produced by Acremonium sp. Strain KR21-2. Geochim. Cosmochim. Acta 74, 5463-5477.

Taylor, S. R. and McLennan, S. M. (1985) The Continental Crust: Its Composition and Evolution. Blackwell, Boston, 312 pp.

Tyler, G. (2004) Rare earth elements in soil and plant systems-a review. Plant and Soil. 267 (1-2), 191-206.

Verplanck, P. P., Taylor, H. E., Nordstrom, D. K. and Barber, L. B. (2005) Aqueous Stability of Gadolinium in Surface Waters Receiving Sewage Treatment Plant Effluent, Boulder Creek, Colorado. Environ. Sci. Technol. 39 (18), 6923-6929.

Wang, S. H., Zhang, N., Chen, H., Li, L., Yan, W. (2014) The surface sediment type and their rare earth element characteristics from the continental shelf of the northern South China Sea. Cont. Shelf Res. 88, 185-202.

Wang, L. and Liang, T. (2015) Geochemical fractions of rare earth elements in soil around a mine tailing in Baotou, China. Sci. Rep. 5, 12483.

Wang, L., Han, X., Liang, T., Guo, Q., Li, J., Dai, L. and Ding, S. (2018) Discrimination of rare earth element geochemistry and co-occurrence in sediment from Poyang Lake, the largest freshwater lake in China. Chemosphere $217,851-857$. 
678

679

680

681

682

683

684

685

686

687

688

689

690

691

692

693

694

695

696

697

698

699

Wei, L., Guo, H. M., Xie, Z. H. and Li, Z. P. (2010) Rare earth elements geochemistry and its implication for sediment provenance in the Beijing plain, Earth Sci. Front. 17(6), 72-80. (In Chinese with English abstract).

Wei, F. S., Liu, T. L., Teng, E. J. and Rui, K. S. (1991) A survey on the background contents of 15 rare earth elements in Chinese soil. Environ. Sci. 12, 78-82 (In Chinese with English abstract).

Wu, J., Lu, J., Li, L. M., Min, X. Y., Zhang, Z. H. and Luo Y. M. (2018) Distribution, pollution, and ecological risks of rare earth elements in soil of the northeastern Qinghai-tibet plateau. Hum. Ecol. Risk Assess. 25(3), 1-16.

Xie, X. J., Wang, Y. X., Ellis, A., Liu, C. X., Duan, M. Y. and Li, J. X. (2014) Impact of sedimentary provenance and weathering on arsenic distribution in aquifers of the Datong basin, China: Constraints from elemental geochemistry. J. Hydrol. $519,3541-3549$.

Xing, L. N., Guo, H. M. and Zhan, Y. H. (2013) Groundwater hydrochemical characteristics and processes along flow paths in the North China Plain. J. Asian Earth Sci. 70-71, 250-264.

Xu, N., Morgan, B. and W. Rate, A. (2018) From source to sink: Rare-earth elements trace the legacy of sulfuric dredge spoils on estuarine sediments. Sci. Total Environ. 637-638, 1537-1549.

Yan, X. P., Kerrich, R. and Hendry, M. J. (1999) Sequential leachates of multiple grain size fractions from a clay-rich till, Saskatchewan, Canada: implications for controls on the rare earth element geochemistry of porewaters in an aquitard. 
701 Yang, S. Y., Jung, H. S., Choi, M. S. and Li, C. X. (2002) The rare earth element compositions of the Changjiang (Yangtze) and Huanghe (Yellow) river sediments. Earth Planet Sc. Lett. 201, 407-419.

704 Yu, C., Drake, H., Mathurin, F. A. and Åström, M. E. (2017) Cerium sequestration 705 and accumulation in fractured crystalline bedrock: The role of $\mathrm{Mn}-\mathrm{Fe}$ (hydr-) 706 oxides and clay minerals. Geochim. Cosmochim. Acta 199, 370-389.

707 Zhang, Y. and Gao, X. L. (2015) Rare earth elements in surface sediments of a marine 708 coast under heavy anthropogenic influence: The Bohai Bay, China. Estuar. $709 \quad$ Coastal Shelf S. 164, 86-93. 
Table 1 Concentrations of REE and major oxides and REE fractionation indices in the sediment samples from three zones

Table 2 Pearson's correlations between REE concentrations and major oxides, CIA and LOI in the sediment samples from three zones (Y09 (118 m): piedmont, $\mathrm{n}=50$; S30 (184 m): central, n=163; H02 (110 m): littoral, $\mathrm{n}=63$; “**” indicates $\mathrm{p}<0.01$, “*” $p<0.05)$

Figure 1 Study area and sediments sampling locations (boreholes)

Figure 2 Changes of sediment lithology and REE parameters along depth: (a) piedmont borehole Y09, (b) central borehole S30, (c) littoral borehole H02

Figure 3 Ternary diagram of sandstone classification and $\mathrm{Al}_{2} \mathrm{O}_{3}-\mathrm{CaO}+\mathrm{Na}_{2} \mathrm{O}-\mathrm{K}_{2} \mathrm{O}$

722

723

\section{(A-CN-K)}

Figure 4 NASC-normalized REE patterns and absolute REE concentrations in all sediment samples (The line indicates a trend of normalized REE concentrations. The box-whisker shows distributions of absolute REE concentrations; (a) piedmont borehole Y09, (b) central borehole S30, (c) littoral borehole H02)

Figure 5 Total REE concentrations as a function of $(\mathrm{La} / \mathrm{Yb})_{\mathrm{NASC}}(\mathrm{a}), \mathrm{Ce} / \mathrm{Ce} *$ (c) and $\mathrm{Eu} / \mathrm{Eu}^{*}(\mathrm{~d})$; a relationship between CIA and $(\mathrm{La} / \mathrm{Yb})_{\mathrm{NASC}}(\mathrm{b})$ 


\begin{tabular}{|c|c|c|c|c|c|c|c|c|c|c|}
\hline \multirow[b]{2}{*}{$\begin{array}{l}\text { Component } \\
\mathrm{La}\end{array}$} & \multirow[b]{2}{*}{$\begin{array}{c}\text { Unit } \\
\mathrm{mg} / \mathrm{kg}\end{array}$} & \multicolumn{3}{|c|}{$\begin{array}{c}\text { piedmont } \\
\text { Y09 }\end{array}$} & \multicolumn{3}{|c|}{$\begin{array}{c}\text { central } \\
\text { S30 }\end{array}$} & \multicolumn{3}{|c|}{$\begin{array}{c}\text { littoral } \\
\mathrm{H} 02 \\
\end{array}$} \\
\hline & & $\begin{array}{l}\text { Min. } \\
19.54\end{array}$ & $\begin{array}{l}\text { Avg. } \\
40.93\end{array}$ & $\begin{array}{l}\text { Max. } \\
63.81\end{array}$ & $\begin{array}{l}\text { Min. } \\
16.59\end{array}$ & $\begin{array}{l}\text { Avg. } \\
33.16\end{array}$ & $\begin{array}{l}\text { Max. } \\
54.53\end{array}$ & $\begin{array}{l}\text { Min. } \\
16.80\end{array}$ & $\begin{array}{l}\text { Avg. } \\
32.05\end{array}$ & $\begin{array}{l}\text { Max. } \\
43.99\end{array}$ \\
\hline $\mathrm{Ce}$ & $\mathrm{mg} / \mathrm{kg}$ & 39.75 & 82.99 & 135.94 & 31.99 & 66.34 & 108.59 & 31.81 & 63.09 & 87.26 \\
\hline $\operatorname{Pr}$ & $\mathrm{mg} / \mathrm{kg}$ & 4.60 & 9.71 & 14.98 & 3.87 & 7.72 & 12.38 & 3.87 & 7.39 & 10.01 \\
\hline $\mathrm{Nd}$ & $\mathrm{mg} / \mathrm{kg}$ & 16.50 & 35.71 & 55.46 & 13.96 & 28.41 & 45.28 & 13.70 & 27.28 & 36.75 \\
\hline $\mathrm{Sm}$ & $\mathrm{mg} / \mathrm{kg}$ & 3.12 & 6.81 & 10.43 & 2.66 & 5.56 & 8.73 & 2.58 & 5.40 & 7.30 \\
\hline $\mathrm{Eu}$ & $\mathrm{mg} / \mathrm{kg}$ & 0.70 & 1.31 & 1.91 & 0.72 & 1.12 & 1.60 & 0.72 & 1.09 & 1.50 \\
\hline $\mathrm{Gd}$ & $\mathrm{mg} / \mathrm{kg}$ & 2.73 & 6.09 & 9.67 & 2.32 & 4.99 & 7.72 & 2.22 & 4.87 & 6.97 \\
\hline $\mathrm{Tb}$ & $\mathrm{mg} / \mathrm{kg}$ & 0.45 & 0.97 & 1.52 & 0.34 & 0.78 & 1.24 & 0.34 & 0.78 & 1.10 \\
\hline Dy & $\mathrm{mg} / \mathrm{kg}$ & 2.49 & 5.41 & 8.35 & 1.97 & 4.34 & 6.75 & 1.97 & 4.32 & 6.03 \\
\hline Ho & $\mathrm{mg} / \mathrm{kg}$ & 0.55 & 1.11 & 1.70 & 0.40 & 0.88 & 1.35 & 0.41 & 0.88 & 1.22 \\
\hline $\mathrm{Er}$ & $\mathrm{mg} / \mathrm{kg}$ & 1.53 & 3.10 & 4.42 & 1.11 & 2.46 & 3.72 & 1.08 & 2.47 & 3.40 \\
\hline $\mathrm{Tm}$ & $\mathrm{mg} / \mathrm{kg}$ & 0.26 & 0.53 & 0.75 & 0.19 & 0.42 & 0.64 & 0.20 & 0.43 & 0.59 \\
\hline $\mathrm{Yb}$ & $\mathrm{mg} / \mathrm{kg}$ & 1.59 & 3.20 & 4.47 & 1.24 & 2.64 & 3.93 & 1.18 & 2.62 & 3.50 \\
\hline $\mathrm{Lu}$ & $\mathrm{mg} / \mathrm{kg}$ & 0.27 & 0.53 & 0.73 & 0.20 & 0.44 & 0.66 & 0.21 & 0.44 & 0.60 \\
\hline $\mathrm{Y}$ & $\mathrm{mg} / \mathrm{kg}$ & 14.60 & 30.20 & 44.94 & 10.53 & 23.61 & 36.11 & 10.80 & 23.59 & 34.05 \\
\hline $\mathrm{SiO}_{2}$ & $\mathrm{wt} \%$ & 55.55 & 66.77 & 78.36 & 35.71 & 56.62 & 71.56 & 32.04 & 59.51 & 77.03 \\
\hline $\mathrm{Fe}_{2} \mathrm{O}_{3}$ & $\mathrm{wt} \%$ & 1.86 & 5.46 & 9.86 & 2.00 & 4.45 & 6.51 & 1.83 & 4.06 & 6.61 \\
\hline $\mathrm{Al}_{2} \mathrm{O}_{3}$ & $\mathrm{wt} \%$ & 6.37 & 10.47 & 14.14 & 7.42 & 10.95 & 13.82 & 7.32 & 12.18 & 15.96 \\
\hline $\mathrm{MgO}$ & $\mathrm{wt} \%$ & 0.27 & 1.38 & 2.41 & 1.01 & 2.34 & 3.70 & 0.61 & 2.14 & 5.27 \\
\hline $\mathrm{CaO}$ & $\mathrm{wt} \%$ & 0.40 & 1.25 & 5.45 & 0.97 & 7.01 & 19.23 & 1.30 & 6.12 & 18.63 \\
\hline $\mathrm{Na}_{2} \mathrm{O}$ & $\mathrm{wt} \%$ & 0.15 & 1.15 & 2.28 & 0.66 & 1.65 & 3.31 & 0.52 & 3.38 & 46.29 \\
\hline $\mathrm{K}_{2} \mathrm{O}$ & $\mathrm{wt} \%$ & 1.89 & 2.58 & 3.37 & 1.55 & 2.20 & 2.82 & 1.57 & 2.26 & 2.89 \\
\hline $\mathrm{MnO}$ & $\mathrm{wt} \%$ & 0.02 & 0.07 & 0.30 & 0.03 & 0.07 & 0.15 & 0.04 & 0.07 & 0.16 \\
\hline $\mathrm{P}_{2} \mathrm{O}_{5}$ & $\mathrm{wt} \%$ & 0.06 & 0.1 & 0.69 & 0.13 & 0.25 & 0.36 & 0.04 & 0.12 & 0.17 \\
\hline $\mathrm{TiO}_{2}$ & $\mathrm{wt} \%$ & 0.26 & 0.69 & 0.99 & 0.44 & 0.93 & 1.54 & 0.51 & 0.96 & 1.22 \\
\hline LOI & $\mathrm{wt} \%$ & 1.13 & 3.88 & 7.36 & 3.12 & 8.56 & 19.91 & 2.5 & 8.02 & 17.56 \\
\hline$\sum \mathrm{REE}$ & $\mathrm{mg} / \mathrm{kg}$ & 109 & 229 & 354 & 89 & 183 & 291 & 88 & 177 & 238 \\
\hline LREE & $\mathrm{mg} / \mathrm{kg}$ & 84 & 178 & 279 & 70 & 142 & 231 & 7 & 136 & 183 \\
\hline HREE & $\mathrm{mg} / \mathrm{kg}$ & 9.93 & 20.94 & 31.59 & 7.77 & 16.96 & 26.00 & 7.61 & 16.81 & 23.39 \\
\hline LREE/HREE & - & 6.93 & 8.43 & 10.83 & 7.51 & 8.36 & 9.69 & 7.33 & 8.15 & 9.80 \\
\hline $\mathrm{Ce} / \mathrm{Ce}^{*}$ & - & 0.69 & 0.91 & 1.17 & 0.85 & 0.90 & 0.98 & 0.80 & 0.89 & 0.98 \\
\hline $\mathrm{Eu} / \mathrm{Eu}^{*}$ & - & 0.82 & 0.91 & 1.07 & 0.83 & 0.95 & 1.31 & 0.86 & 0.95 & 1.34 \\
\hline $\mathrm{Gd} / \mathrm{Gd}^{*}$ & - & 0.95 & 1.06 & 1.15 & 0.93 & 1.05 & 1.12 & 0.87 & 1.04 & 1.10 \\
\hline$(\mathrm{Y} / \mathrm{Ho})_{\mathrm{NASC}}$ & - & 1.09 & 1.13 & 1.22 & 1.04 & 1.11 & 1.17 & 1.06 & 1.11 & 1.19 \\
\hline$(\mathrm{La} / \mathrm{Yb})_{\mathrm{NASC}}$ & - & 0.86 & 1.23 & 1.15 & 1.03 & 1.21 & 1.49 & 0.91 & 1.09 & 1.49 \\
\hline
\end{tabular}


Table 2

\begin{tabular}{|c|c|c|c|c|c|c|c|c|c|c|c|}
\hline & borehole & REE & $\mathrm{SiO}_{2}$ & $\mathrm{Fe}_{2} \mathrm{O}_{3}$ & $\mathrm{Al}_{2} \mathrm{O}_{3}$ & $\mathrm{MgO}$ & $\mathrm{CaO}$ & $\mathrm{Na}_{2} \mathrm{O}$ & $\mathrm{K}_{2} \mathrm{O}$ & LOI & CIA \\
\hline \multirow{3}{*}{ REE } & Y09 & 1 & & & & & & & & & \\
\hline & S30 & 1 & & & & & & & & & \\
\hline & H02 & 1 & & & & & & & & & \\
\hline \multirow{3}{*}{$\mathrm{SiO}_{2}$} & Y09 & $-0.79 * *$ & 1 & & & & & & & & \\
\hline & S30 & $-0.58 * *$ & 1 & & & & & & & & \\
\hline & H02 & $-0.67 * *$ & 1 & & & & & & & & \\
\hline \multirow{3}{*}{$\mathrm{Fe}_{2} \mathrm{O}_{3}$} & Y09 & $0.72 * *$ & $-0.92 * *$ & 1 & & & & & & & \\
\hline & S30 & $0.90 * *$ & $-0.56^{* *}$ & 1 & & & & & & & \\
\hline & H02 & $0.89^{* *}$ & $-0.67 * *$ & 1 & & & & & & & \\
\hline \multirow{3}{*}{$\mathrm{Al}_{2} \mathrm{O}_{3}$} & Y09 & $0.67 * *$ & $-0.77 * *$ & $0.85^{* *}$ & 1 & & & & & & \\
\hline & $\mathrm{S} 30$ & $0.51 * *$ & $0.249 * *$ & $0.60 * *$ & 1 & & & & & & \\
\hline & H02 & 0.19 & $0.430 * *$ & $0.30^{*}$ & 1 & & & & & & \\
\hline \multirow{3}{*}{$\mathrm{MgO}$} & Y09 & $0.55^{* *}$ & $-0.77 * *$ & $0.79 * *$ & $0.55^{* *}$ & 1 & & & & & \\
\hline & $\mathrm{S} 30$ & $0.66 * *$ & $-0.61 * *$ & $0.79 * *$ & $0.31 * *$ & 1 & & & & & \\
\hline & H02 & $0.71 * *$ & $-0.84 * *$ & $0.71 * *$ & $-0.32 * *$ & 1 & & & & & \\
\hline \multirow{3}{*}{$\mathrm{CaO}$} & Y09 & -0.06 & -0.11 & 0.05 & $-0.342^{*}$ & $0.44 * *$ & 1 & & & & \\
\hline & $\mathrm{S} 30$ & 0.12 & $-0.82 * *$ & 0.04 & $-0.72 * *$ & $0.21 *$ & 1 & & & & \\
\hline & H02 & 0.15 & $-0.58 * *$ & 0.06 & $-0.40 * *$ & 0.12 & 1 & & & & \\
\hline \multirow{2}{*}{$\mathrm{Na}_{2} \mathrm{O}$} & Y09 & $-0.74 * *$ & $0.78 * *$ & $-0.70 * *$ & $-0.79 * *$ & $-0.31 *$ & $0.31 *$ & 1 & & & \\
\hline & $\mathrm{S} 30$ & $-0.81 * *$ & $0.79 * *$ & $-0.75^{* *}$ & $-0.24 *$ & $-0.57 * *$ & $-0.44 * *$ & 1 & & & \\
\hline
\end{tabular}




\begin{tabular}{|c|c|c|c|c|c|c|c|c|c|c|c|}
\hline & $\mathrm{H} 02$ & 0.19 & $-0.51 * *$ & 0.13 & $-0.76^{* *}$ & $0.68 * *$ & -0.07 & 1 & & & \\
\hline \multirow{3}{*}{$\mathrm{K}_{2} \mathrm{O}$} & Y09 & 0.13 & -0.09 & 0.001 & -0.125 & -0.19 & $-0.40 * *$ & -0.18 & 1 & & \\
\hline & $\mathrm{S} 30$ & 0.17 & $0.26^{* *}$ & $0.36^{* *}$ & $0.58 * *$ & 0.17 & $-0.61 * *$ & 0.09 & 1 & & \\
\hline & $\mathrm{H} 02$ & 0.17 & -0.003 & $0.46^{* *}$ & $0.49^{* *}$ & 0.08 & $-0.39 * *$ & -0.19 & 1 & & \\
\hline \multirow{3}{*}{ LOI } & Y09 & $0.50 * *$ & $-0.84 * *$ & $0.60 * *$ & $0.46^{* *}$ & $0.44 * *$ & 0.03 & $-0.52 * *$ & -0.003 & 1 & \\
\hline & $\mathrm{S} 30$ & $0.21 *$ & $0.91 * *$ & 0.16 & $0.64 * *$ & $0.23^{*}$ & $0.83 * *$ & $0.52 * *$ & 1.74 & 1 & \\
\hline & H02 & $0.27 *$ & $0.85^{* *}$ & $0.25^{*}$ & $0.47 * *$ & $0.42 * *$ & $0.62 * *$ & -0.04 & -0.03 & 1 & \\
\hline \multirow{3}{*}{ CIA } & Y09 & $0.51 * *$ & $-0.75^{* *}$ & $0.82 * *$ & $0.54 * *$ & $0.44 * *$ & -0.003 & $-0.66 * *$ & $-0.04 * *$ & $0.56^{* *}$ & 1 \\
\hline & $\mathrm{S} 30$ & 0.26 & 0.06 & $0.36^{* *}$ & 0.02 & 0.09 & $-0.52 * *$ & -0.06 & $0.34 * *$ & 0.002 & 1 \\
\hline & $\mathrm{H} 02$ & $0.35^{* *}$ & 0.03 & $0.48^{* *}$ & $0.25^{*}$ & $0.26^{*}$ & $-0.29 *$ & -0.01 & $0.21 *$ & -0.01 & 1 \\
\hline
\end{tabular}

736

737

738

739

740 


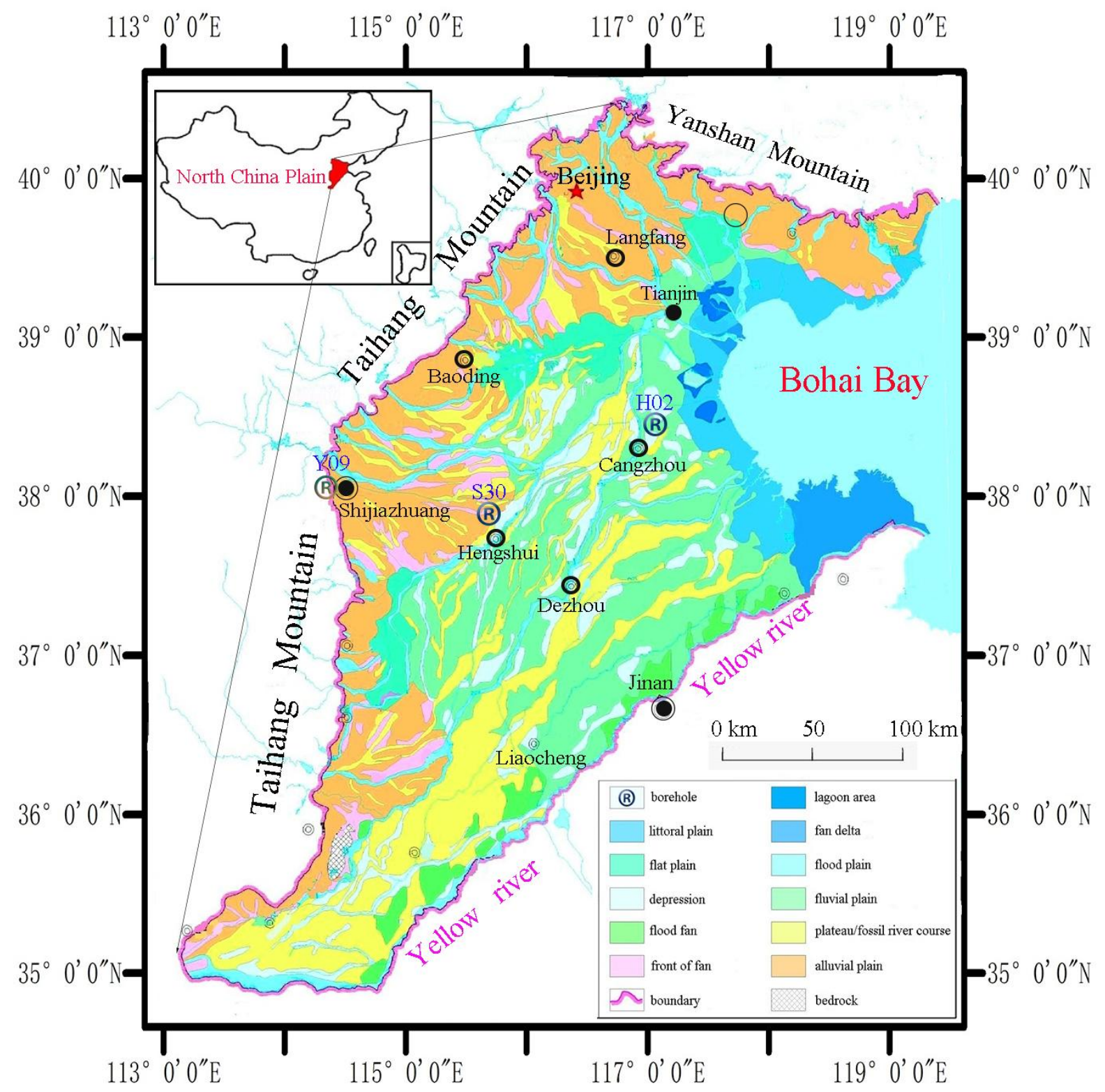

Fig. 1 


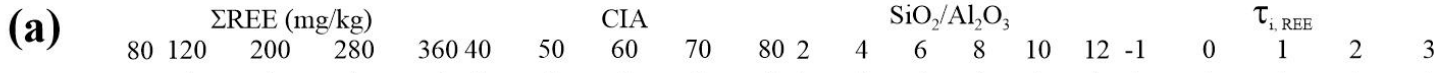
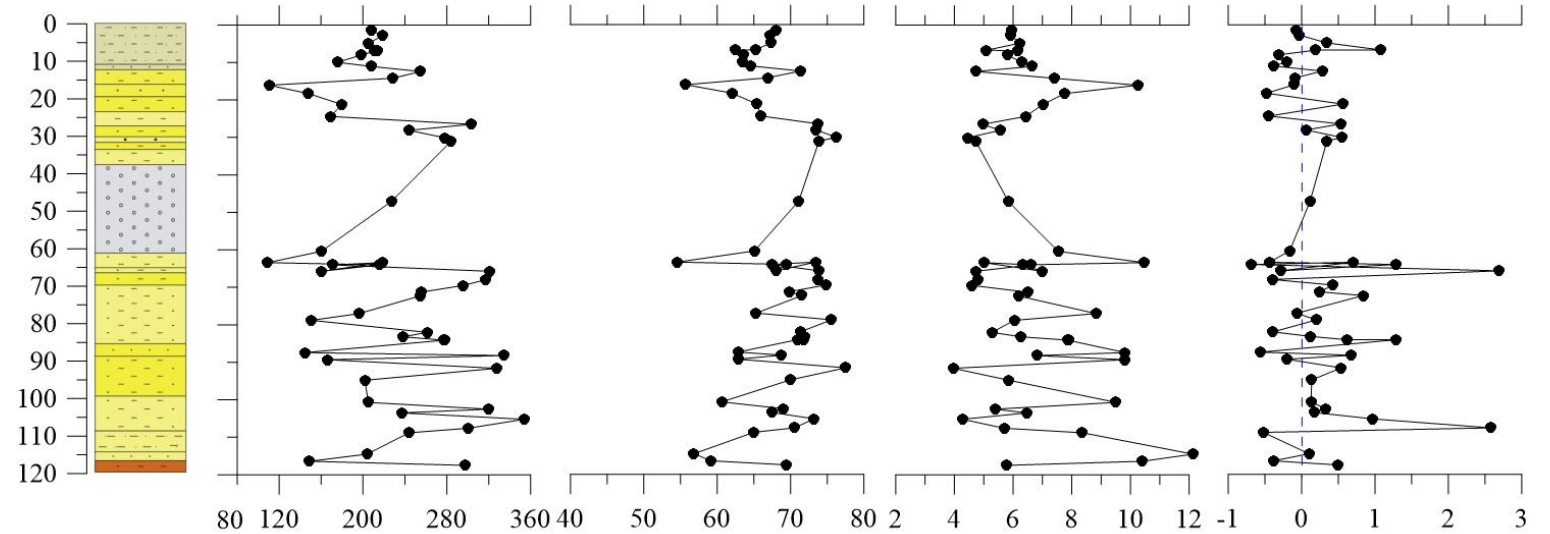

Clay $\because-\cdots$ Silt $\because---$ Silty clay $\because \because \because$ Fine sand $\because \because \because$ Coarse sand $\because \because \circ \circ$ Gravel

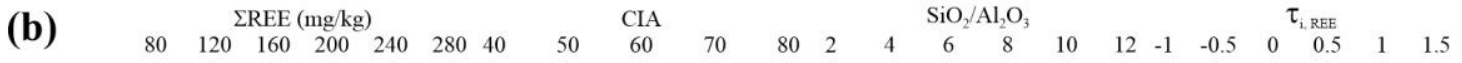
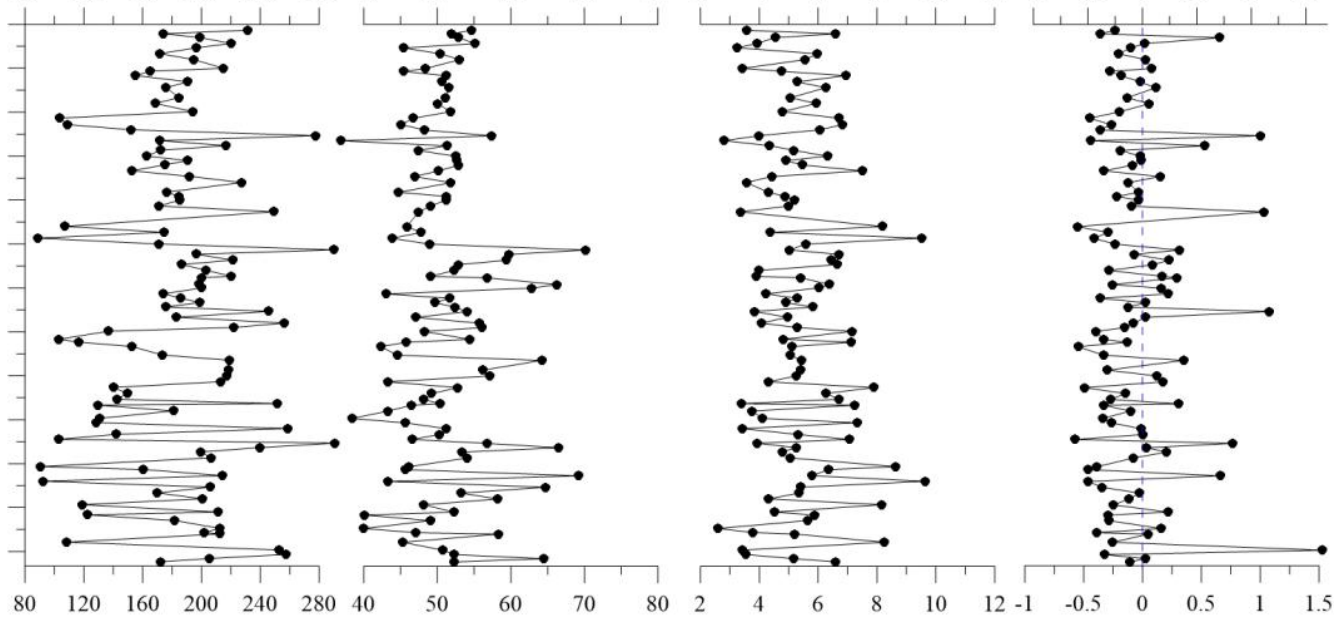

(c) $\quad \sum \operatorname{REE}(\mathrm{mg} / \mathrm{kg})$

CIA

$\mathrm{SiO}_{2} / \mathrm{Al}_{2} \mathrm{O}_{3}$
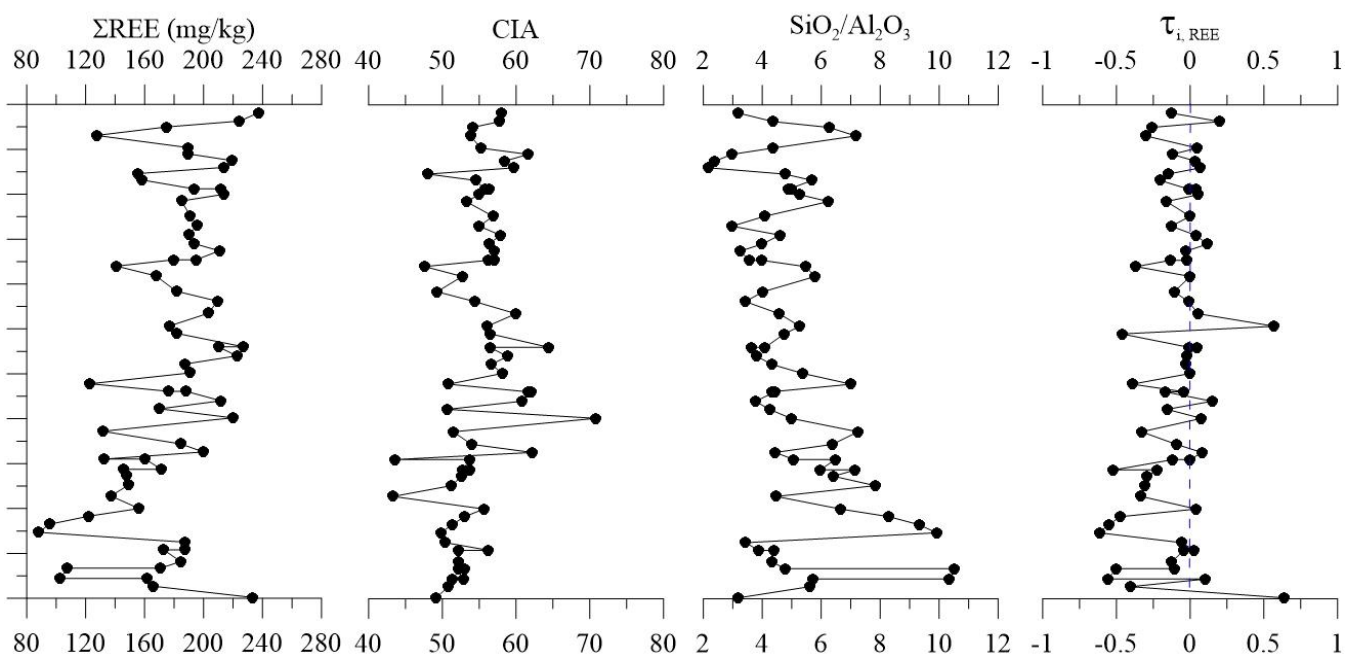

.

Fig. 2 


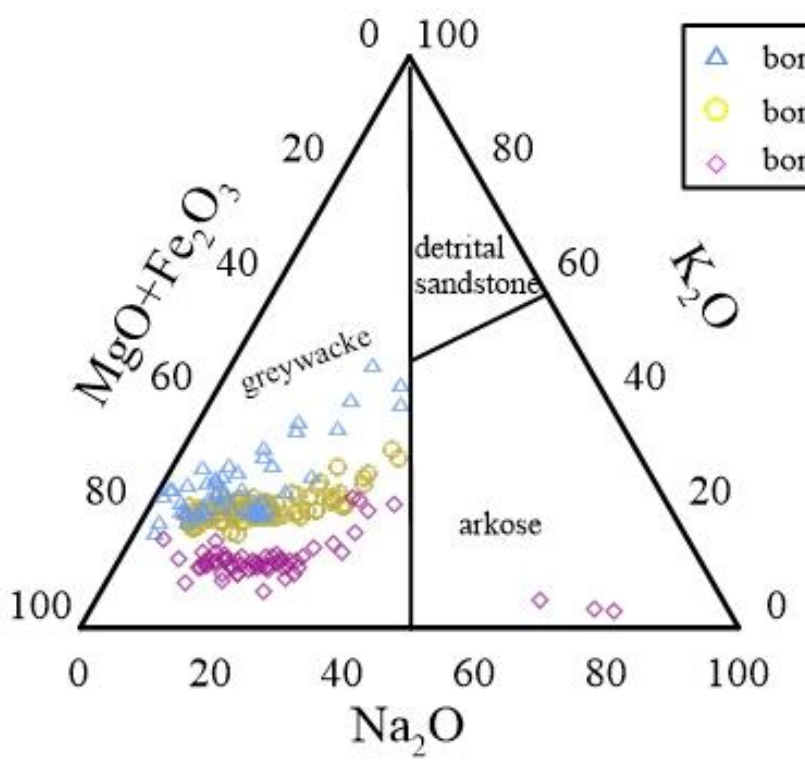

(a)

Fig. 3

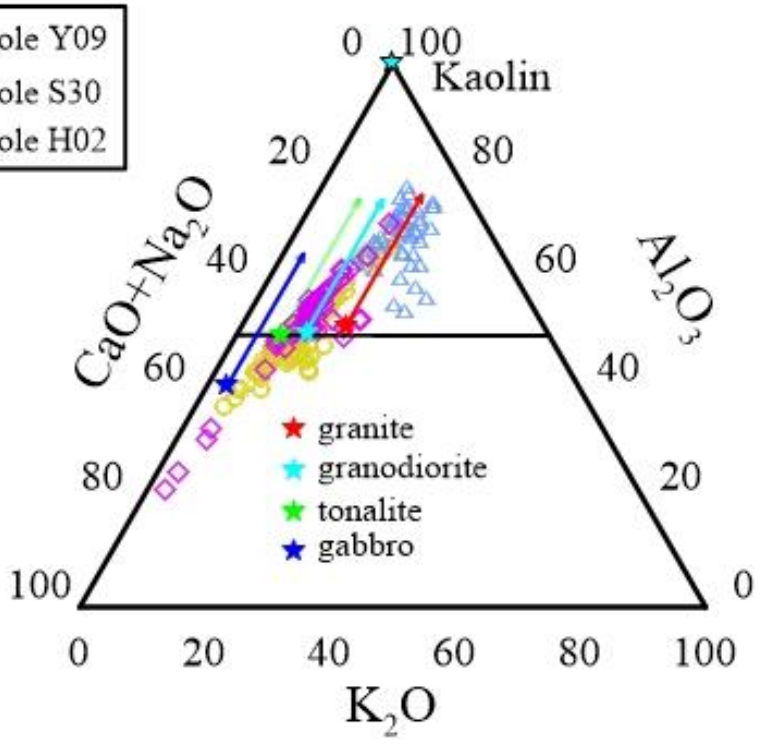

(b) 


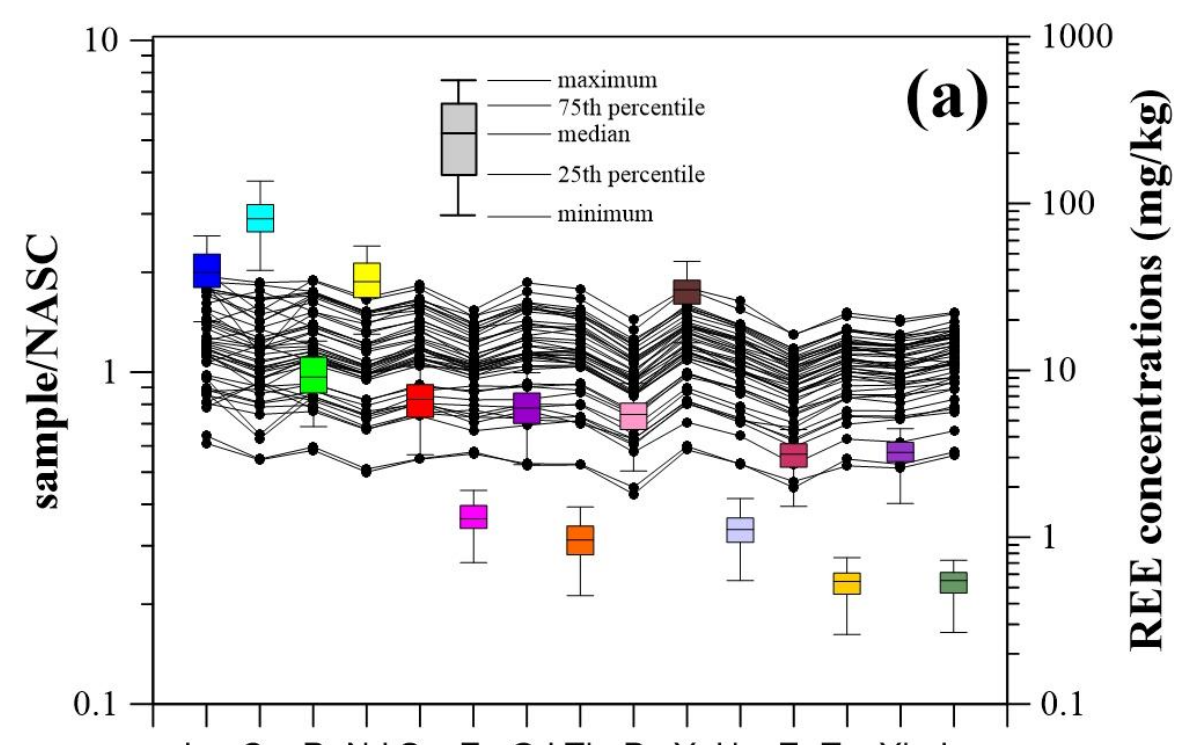

La Ce PrNd Sm Eu Gd Tb Dy Y Ho Er Tm Yb Lu
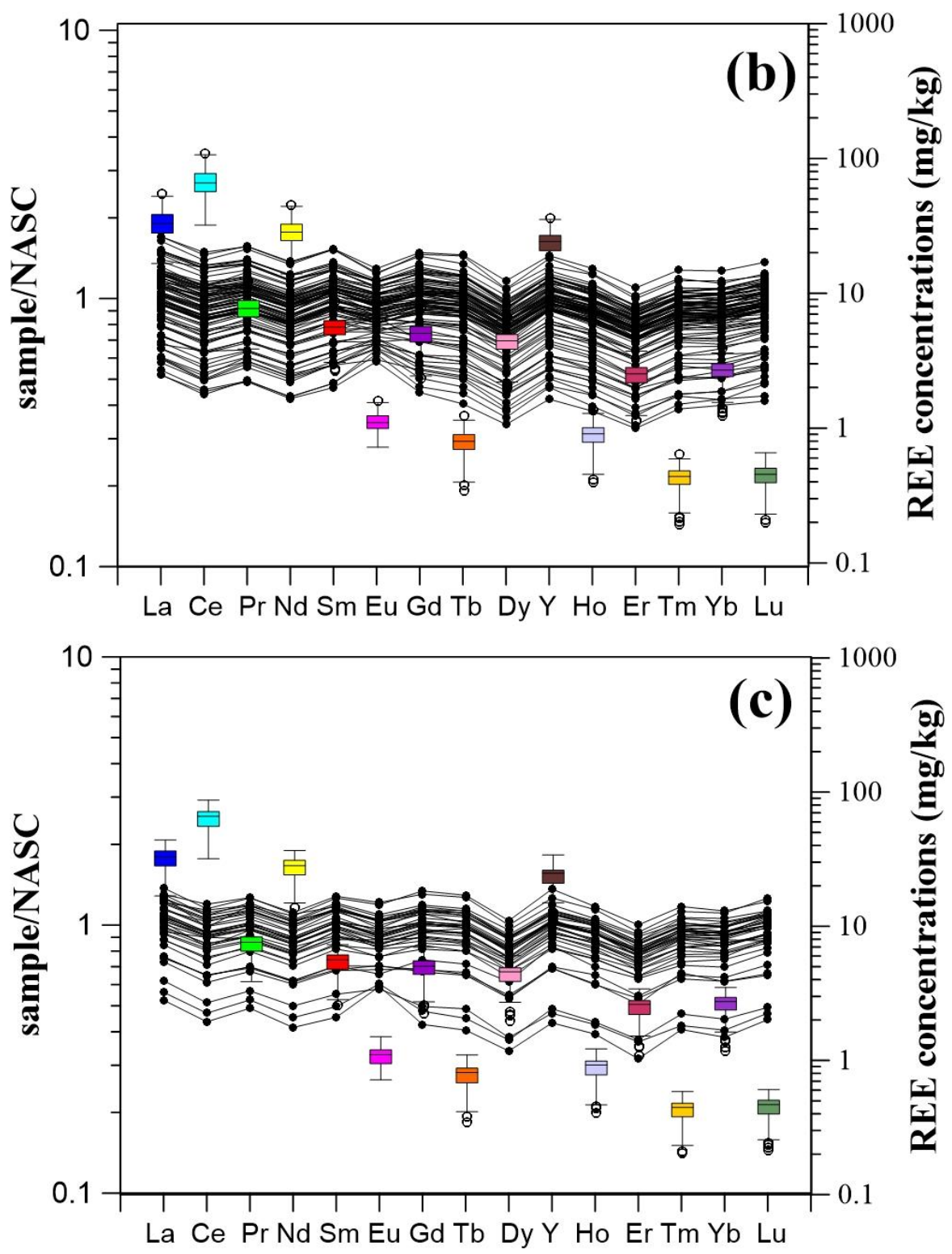

Fig. 4 

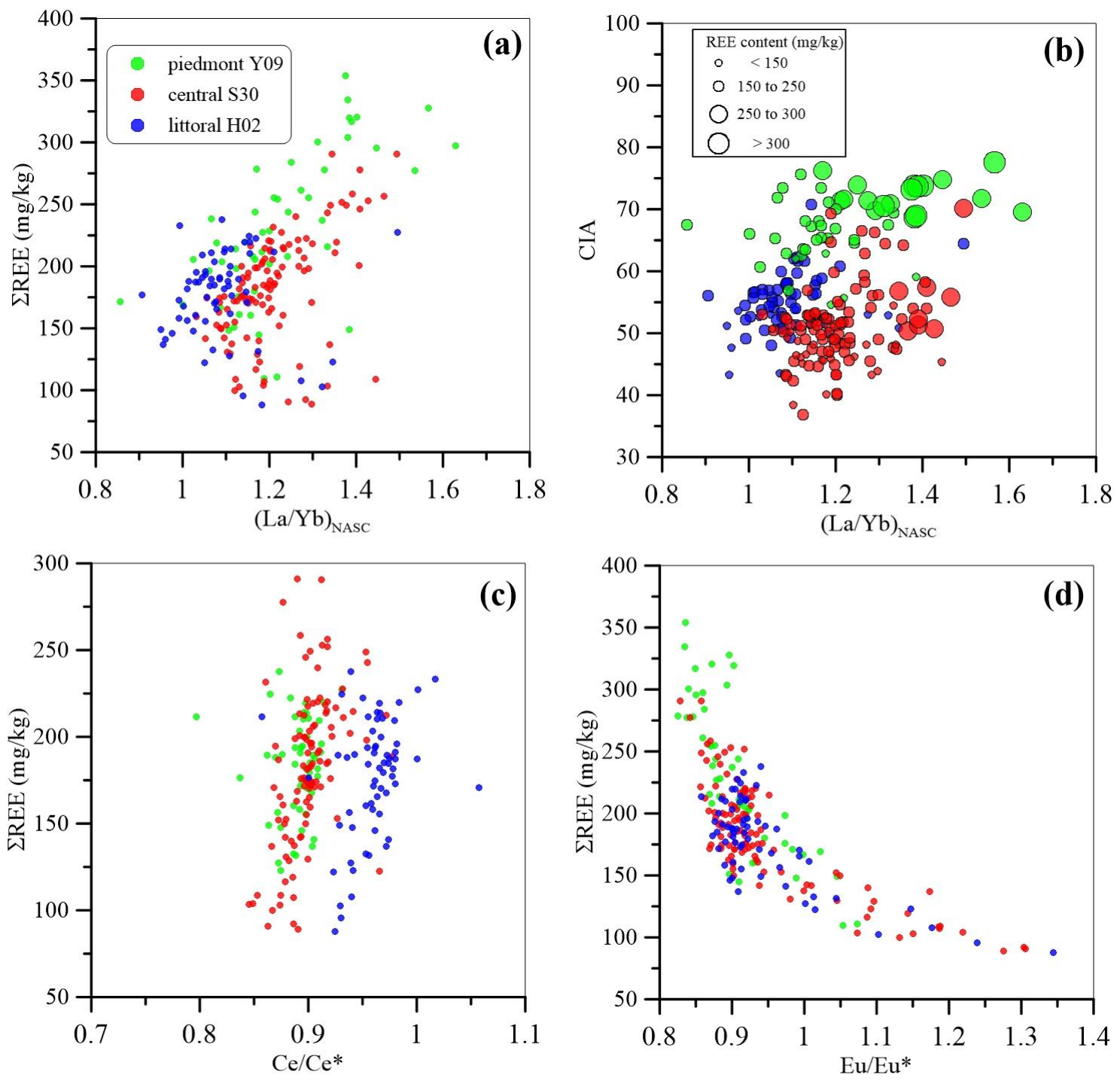